DOI: $10.15838 / \mathrm{esc} / 2015.2 .38 .3$

UDC 330.341, LBC 65.050.1

(C) Ilyin V.A., Morev M.V.

\title{
A new stage of Russian history: trends, specifics and prospects
}

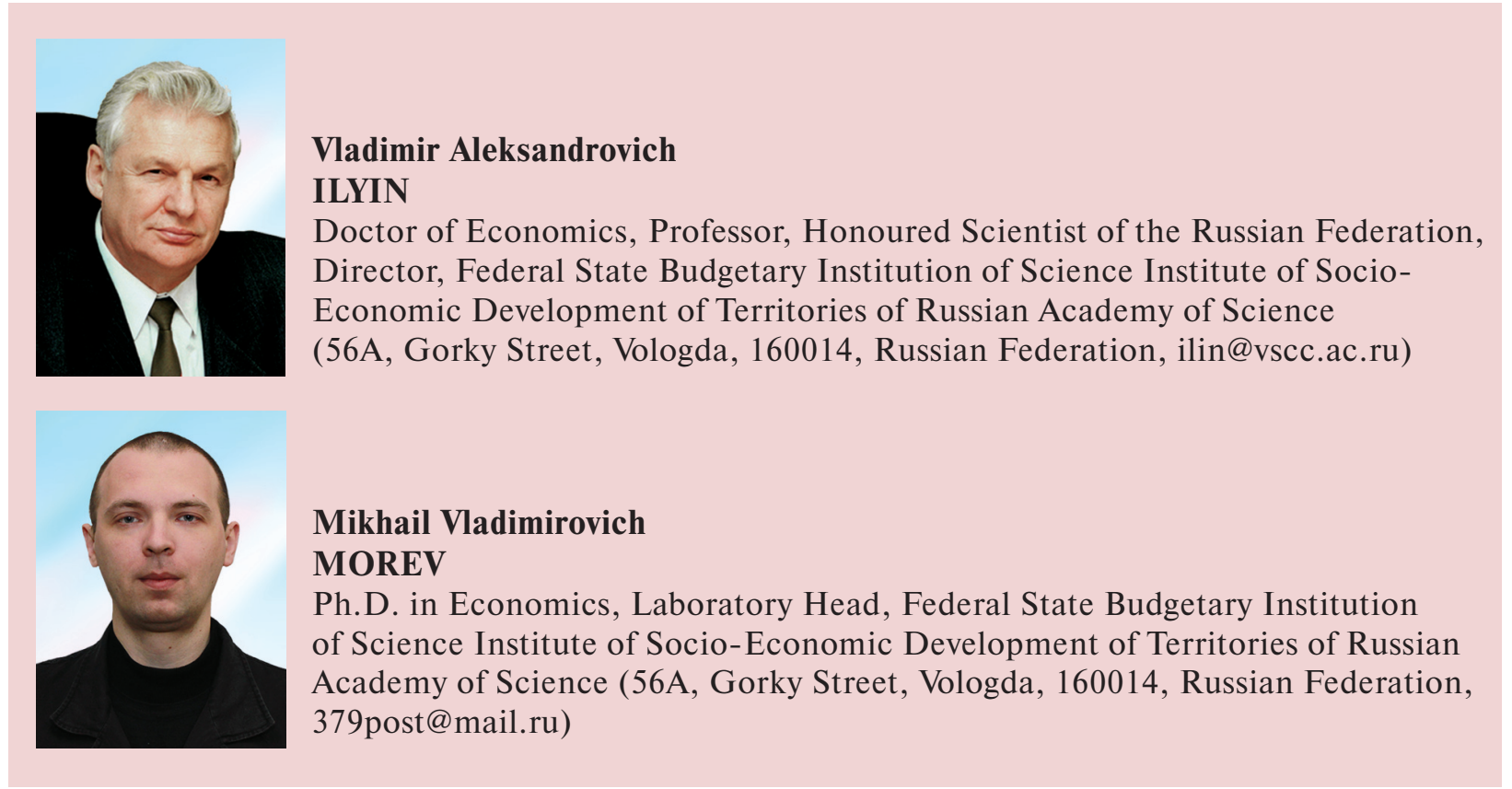

Abstract. The article discusses the trends and specifics of public sentiment in Russia in the 1990s-2010s; it analyzes key events of the recent years that led to the understanding of the present stage of social development as a new era of the post-Soviet period.

The authors consider the interaction between the society and authorities, the role of scientific knowledge in the improvement of public administration efficiency, the development civil society, and also several promising opportunities and current issues of social science.

The article presents the experience of sociological research carried out by ISEDT RAS at the regional level.

The authors discuss key factors that determine the efficiency of interaction between the society and authorities and the success of Russia's further development.

Key words: society, authorities, public administration, sociological knowledge, public opinion monitoring, post-Soviet period. 
G.V. Osipov in the article headlined "Do not miss this chance!" published in the annual report "Sociology and economics of the current social reality. Social and socio-political situation in Russia in 2013” by ISPR RAS writes that, after a long, almost 15-year period of waiting, a "new, resurgent" Russia has finally made its transition to a new age - "bright and life-asserting".

What are qualitative differences of this new era from previous periods of postSoviet history? What are its fundamental characteristics? Can we still speak of a "new phase" in the life of Russia, or the social trends that have emerged in recent years are only a temporary transformation forced by the intricacies of geopolitical events?

Of course, these and many other questions present not only scientific, but also practical, interest, because leading scientists, including Russian researchers (G.V. Osipov, A.V. Yurevich, M.K. Gorshkov, J.T. Toshchenko, etc.), point out that currently economic growth and prosperity of any state depend to a great extent on intangible factors connected with public consciousness, attitude and behavior. It is the subjective factor that "plays a significant and increasingly important role among the factors that determine the content and direction of the changes in the world and

1 Osipov G.V. Ne upustit' predostavivshiisya shans! [Do not Miss This Chance!]. Sotsiologiya i ekonomika sovremennoi sotsial'noi real'nosti. Sotsial'naya i sotsial'nopoliticheskaya situatsiya v Rossii v 2013 godu [Sociology and Economics of the Current Social Reality. Social and Socio-Political Situation in Russia in 2013]. Moscow: ISPI RAN. P. 17. in our country" 2 . It is especially important for Russia, on the background of emotional elation following the events of 2014, and on the eve of the 70th anniversary of the Victory in the Great Patriotic War.

Along with the development of the world civilization and new achievements in science and technology the role of noneconomic factors becomes more and more significant, and this process will obviously continue in the future. Accordingly, the issues that we outline in the beginning of the article, eventually, lead to, perhaps, the main and purely practical question: if we are talking about a "new stage" in the life of Russia, then what will determine the success of this stage and a smooth and efficient transition to the next stage?

To answer this question, we need to find out when a "new phase" of post-Soviet Russian history began. But first let us make two methodological digressions, which, in our opinion, are essential for the proper understanding of the author's viewpoint and explanation of the information base on which we form our conclusions and hypotheses.

First, we specify that there is no and cannot be any clear date or exact time period of the "new stage" of Russian history. We are talking about the trends in social consciousness, and they are not formed simultaneously. Certain circumstances that will be explained further and various events in the life of the

2 Toshchenko J.T. Sotsial'noe nastroenie - fenomen sotsiologicheskoi teorii i praktiki [Social Mood a Phenomenon of Sociological Theory and Practice]. SOTSIS [Sociological Studies], 1998, no. 1, p. 32. 
country form a new phase exclusively in their entirety, providing a complex effect on the transformation of social consciousness and behavior. This can take years, and sometimes even decades.

Second, the article uses the results of opinion polls carried out at the federal and regional levels. These results, rather than official statistics, reflect the trends in public sentiment. The dynamics of public opinion nationwide was analyzed with the use of the research findings of VTSIOM and Levada-Center, the leading Russian centers. We characterized public sentiment in a particular region on the basis of the results of a sociological monitoring carried out by the Institute of Socio-Economic Development of Territories of RAS (ISEDT RAS) since $1996^{3}$. Under the current Russian conditions characterized by a deep and complex differentiation of territories by level and quality of life of the population, cultural specifics, etc., we believe it is extremely important to analyze the dynamics of public opinion at the federal and regional levels simultaneously. It makes the research itself systemic in nature, and

\footnotetext{
3 The public opinion monitoring is carried out by ISEDT RAS in the Vologda Oblast since 1996 once every two months. The volume of a sample population is 1500 people aged 18 and older in the cities of Vologda and Cherepovets, and in eight districts of the Vologda Oblast (Babayevsky District, Velikoustyugsky District, Vozhegodsky District, Gryazovetsky District, Kirillovsky District, Nikolsky District, Tarnogsky District and Sheksninsky District. The representativeness of the sample is ensured by the observance of the proportions between the urban and rural population, the proportions between the inhabitants of settlements of various types (rural communities, small and medium-sized cities), age and sex structure of the oblast's adult population. The method of the survey is a questionnaire poll by place of residence of respondents. Sampling error does not exceed 3\%.
}

the conclusions made according to the research results are more comprehensive and accurate.

The methodology of sociological research conducted by ISEDT RAS meets all the requirements that are necessary for obtaining quality and timely sociological data on public opinion trends in the Vologda Oblast. This, in particular, is proved by close cooperation between the Institute and the state authorities that show a growing interest in the opinions of the Oblast residents. The research has been carried out in the monitoring mode for nearly 20 years, with an emphasis on dynamic changes of perception of social reality by representatives of different sociodemographic categories of the Vologda Oblast population ${ }^{4}$. This allows us to speak with confidence about the unique opportunities for studying transformation processes in the regional community, comparing them with dynamic changes in the Russian society, which are recognized by leading scientific institutions of the country ${ }^{5}$.

4 The public opinion monitoring carried out by ISEDT RAS provides the data on more than 20 sociodemographic categories of the population, divided, in particular, by gender (men, women); age (under 30, 3055 , over 55), educational level (secondary and incomplete secondary, secondary vocational, higher and incomplete higher), assessment of one's own income ( $20 \%$ of the poorest people, $60 \%$ of the people with middle-sized income, $20 \%$ of the most prosperous people), the area of residence ( 8 districts and 2 cities), and also by marital status, occupation, etc.

Taking this opportunity, we would like to express our gratitude to the research team of ISPR RAS and personally to G.V. Osipov for their help and guidance not only in creating the system of sociological research of ISEDT RAS, which is still in demand and continues to develop, but also in the formation of Russian social science in the Vologda land. 
So, when has a new phase of Russian history started? What events have allowed us to speak about a new era of the postSoviet period?

G.V. Osipov points out: "Until the spring of 2014 the Russian Federation has only formally entered the twenty-first century. In reality, from a geopolitical perspective, we were still in the twentieth century" ${ }^{6}$. Indeed, for Russian 2014 became a year that was rich in events, and, perhaps, one of the most crucial periods in the entire 20-year post-Soviet history. The events of 2014, the most important of which, no doubt, is the accession of Crimea and Sevastopol to the Russian Federation, have shown that "identity with the Russians that involves the identification of oneself with the country and its people and that is in the basis of the Russian civilizational project has been deeply rooted and has become widespread in the minds of the population, although it was in a "sleep", latent state"?.

The speech of the President of the Russian Federation in Munich on February 10, 2007 became one of the first crucial events that led to a new stage in the life of the Russian society and laid its foundation. Vladimir Putin's speech became the

6 Osipov G.V. Ne upustit' predostavivshiisya shans! [Do not Miss This Chance!]. Sotsiologiya i ekonomika sovremennoi sotsial'noi real'nosti. Sotsial'naya $i$ sotsial'no-politicheskaya situatsiya v Rossii v 2013 godu [Sociology and Economics of the Current Social Reality. Social and Socio-Political Situation in Russia in 2013]. Moscow: ISPI RAN. P. 17.

7 Gorshkov M.K. "Russkaya mechta": opyt sotsiologicheskogo izmereniya [A "Russian Dream": the Experience of Sociological Assessment]. Sotsiologicheskie issledovaniya [Sociological Studies], 2012, no. 12, p. 10. "prologue to the launch of Russia's independent foreign policy resulted in the Syrian triumph, when Russia for the first time in recent history managed to stop the aggression of the world leader, the United States, against a sovereign country" ".

Russian President's speech in Munich can, without exaggeration, be called historic. "Never before in the past decades has the Russian leader made such a clear and adamant statement concerning the image of the future in international politics. All the previous statements on this subject were very ambiguous. This time, President Vladimir Putin not just commented on the current events or voiced Russia's opinion on some issue; he demonstrated the will of Russia as a global geopolitical power to participate in shaping the future world order" 9 .

Vladimir Putin's Munich Speech laid the foundation of the national idea, which is, perhaps, the main characteristic of the new, modern stage in the life of the country. At that time, however, the Russians did not fully perceived and realized the conceptual character of the RF President's speech,

8 Stepanov A.D. Rossiya i mir vstupayut v novuyu epokhu, v kotoroi ot nashei strany budet zaviset' mnogoe [Russia and the World are Entering a New Era in Which a Lot will Depend on Our Country]. Informatsionno-analiticheskaya sluzhba "Russkaya narodnaya liniya" [Information-Analytical Service "Russian National Line"]. Available at: http://ruskline.ru/news_ rl/2013/09/20/valdajskaya_rech_putina

9 Dugin A.G. Ekho "myunkhenskoi rechi”. Prezident Putin vstupil na put' geopoliticheskoi revolyutsii [Echo of the Munich Speech. President Putin has Embarked on the Path of Geopolitical Revolution]. Available at: http:// oko-planet.su/politik/politikrus/230532-aleksandrdugin-eho-myunhenskoy-rechi-prezident-putin-vstupilna-put-geopoliticheskoy-revolyucii.html 
Figure 1. Dynamics of the level of approval of the performance of the President of the Russian Federation by the residents of the Russian Federation and the Vologda Oblast (\% of the number of respondents) ${ }^{\star}$

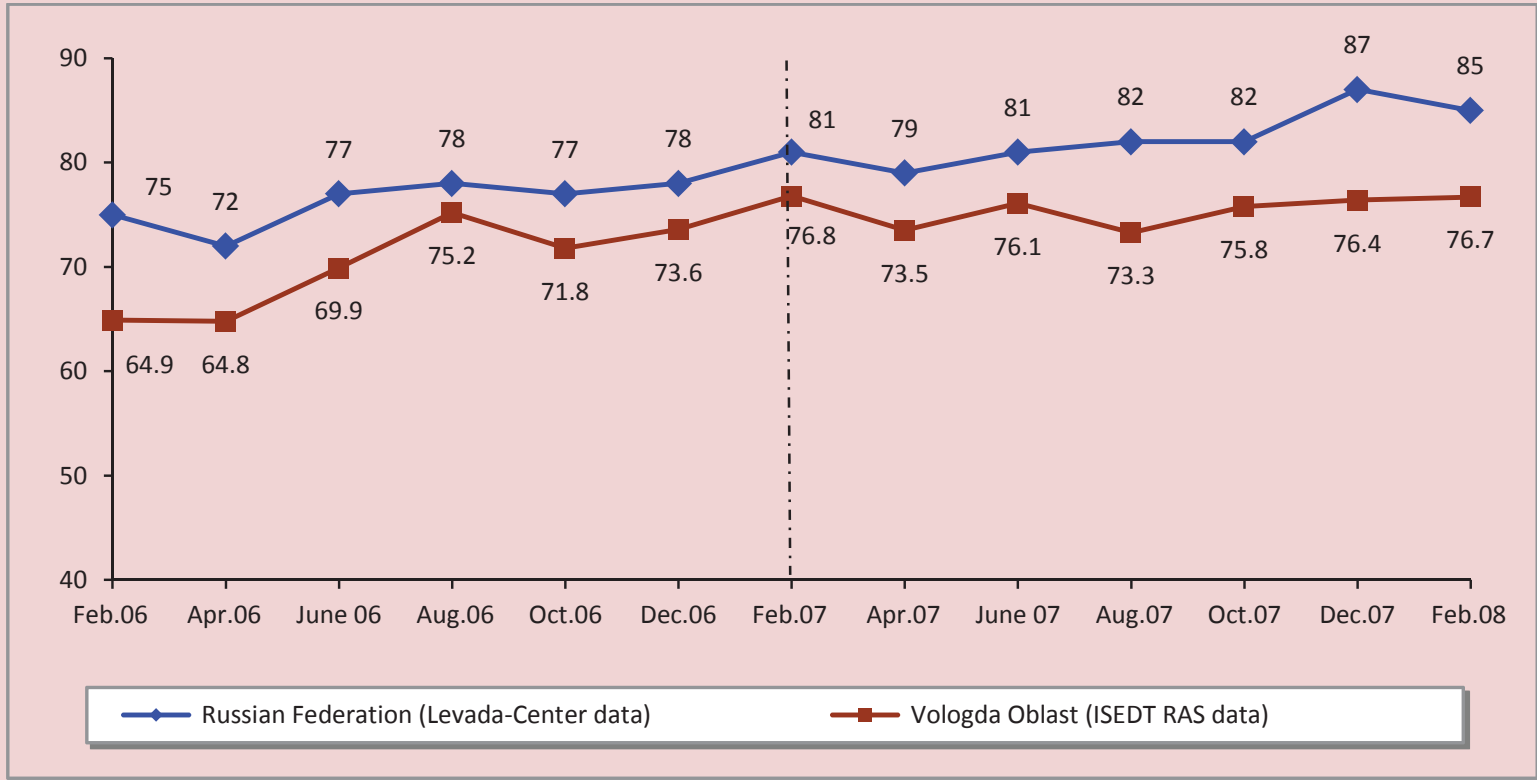

* The graph presents the data for the periods: January 2006 - February 2007 and February 2007 - February 2008, i.e. for the 6 surveys before and after Vladimir Putin's Munich Speech.

since after that there were no significant changes in the dynamics of public opinion on the performance of the President. This was partly due to the fact that in May 2008 Dmitry Medvedev assumed office; besides, for the majority of the population the essence of Vladimir Putin's Munich Speech was obscured by the onset of the global financial crisis. Anyway, we did not observe any steady and sharp increase of support to V. Putin after February 2007 either at the federal or at the regional level (fig. 1).

We cannot say that the starting point of the "new stage" is the beginning of Vladimir Putin's third presidential term, which was marked by a series of the May decrees, the very idea of which was certainly perceived with optimism by the population, because the decrees dealt with the most pressing social and economic problems. After Vladimir Putin was elected President, Russia was still waiting for the new century, and was consolidating its efforts to speed up this process ${ }^{10}$.

People were waiting for the beginning of V. Putin's third presidential term. Perhaps, many of them were waiting for this since the end of his second presidential

${ }^{10}$ Osipov G.V. Ne upustit' predostavivshiisya shans! [Do not Miss This Chance!]. Sotsiologiya i ekonomika sovremennoi sotsial'noi real'nosti. Sotsial'naya i sotsial'nopoliticheskaya situatsiya $v$ Rossii v 2013 godu [Sociology and Economics of the Current Social Reality. Social and Socio-Political Situation in Russia in 2013]. Moscow: ISPI RAN. P. 17. 
term; and the closer this point came, the stronger became the hopes of the society for significant, actual improvement of financial welfare and functioning of the social sphere. But, it turned out that the implementation of the President's May decrees did not bring the effect desired; there emerged certain problems that have not been solved yet. For various reasons (which are all well-known and in the present context do not have to be explained) the hopes of the Russians for the country's step forward once again were reduced to the question of how efficiently or inefficiently the problems existing in the country are solved. As a result, any upsurge of emotional state, or growth of people's support to the President were out of the question at the federal and regional level, after the presidential election (March 4, 2012) and the inauguration of the President of the Russian Federation (May 7, 2012) (fig. 2).

V.V. Putin's speech at the meeting of the Valdai International Discussion Club on September 19, 2013, which was a logical continuation of his Munich Speech, became, perhaps, the key event for the "new stage" in the life of the country. The President of the Russian Federation in this very speech formulated an ideological paradigm of development, which the state is planning to follow: "It is evident

Figure 2. Dynamics of the level of approval of the performance of the President of the Russian Federation by the residents of the Russian Federation and the Vologda Oblast (\% of the number of respondents)

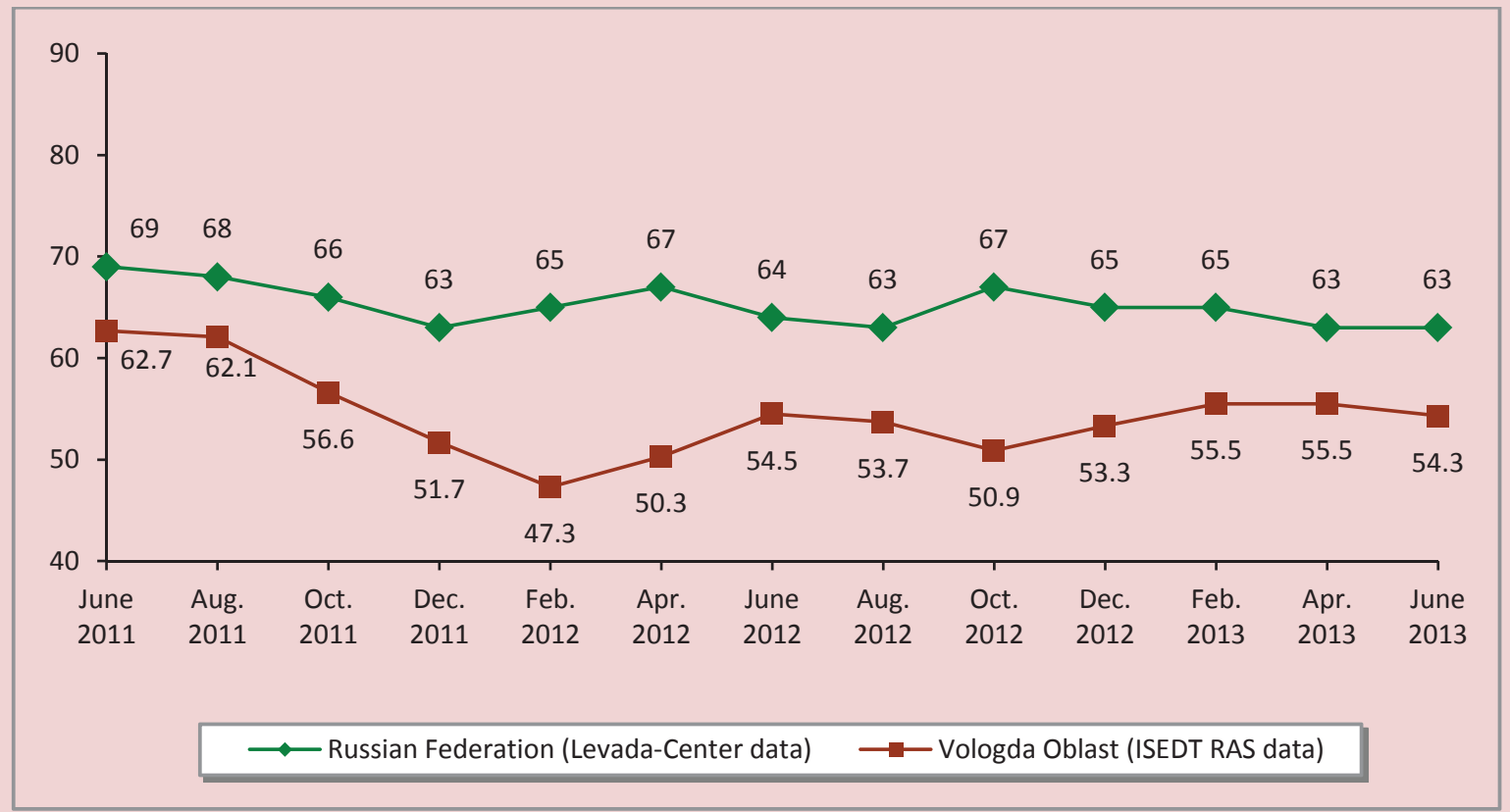

* The graph presents the data for the periods: June 2011 - June 2012 and June 2012 - June 2013, i.e. for the six surveys before and after Vladimir Putin's Munich Speech. 
that it is impossible to move forward without spiritual, cultural and national self-determination. Without this we will not be able to withstand internal and external challenges, nor we will succeed in global competitions" $"$.

How was Vladimir Putin's Valdai Speech perceived in the society? It was viewed as "the first large-scale attempt by the Russian authorities to formulate a new political ideology for Russia after the collapse of the Soviet Union, and also as an attempt to consider in a critical way the values that should lie at the foundation of the new Russian identity, Eurasian world and international relations" 12 . The President has proved himself as "the heir to the Russian conservative political tradition" 13 and "the critic of the entire current model of development of Western civilization" ${ }^{14}$.

${ }^{11}$ Putin V.V. Rech' na zasedanii mezhdunarodnogo diskussionnogo kluba "Valdai" 19 sentyabrya 2013 g. [Vladimir Putin's Speech at the Session of the Valdai International Discussion Club, September 19, 2013]. Available at: http://www.kremlin.ru/events/president/ news/19243

${ }^{12}$ Makhmudov R. Valdaiskaya rech' Vladimira Putina: kriticheskii analiz [Vladimir Putin's Valdai Speech: a Critical Analysis]. Informatsionnyi portal http://www.12news.uz/ [Information Portal http:// www.12news.uz/]. Available at: http://www.12news. uz/news/2013/09/30/валдайская-речь-владимирапутина-кри/

${ }_{13}$ Stepanov A.D. Rossiya i mir vstupayut v novuyu epokhu, v kotoroi ot nashei strany budet zaviset' mnogoe [Russia and the World are Entering a New Era in Which a Lot will Depend on Our Country]. Informatsionno-analiticheskaya sluzhba "Russkaya narodnaya liniya" [Information-Analytical Service "Russian National Line"]. Available at: http://ruskline. ru/news_rl/2013/09/20/valdajskaya_rech_putina

${ }^{14}$ Akopov P.E. Valdai posle Myunkhena [Valdai after Munich]. Gazeta "Vzglyad" [Newspaper "Outlook"], September 20, 2013. Available at: http://vz.ru/politics/ 2013/9/20/651345.html
Moreover, the conceptual nature of the President's Valdai Speech was pointed out not only in Russia but also abroad ("Putin delivered his speech not in the Parliament of the Russian Federation, not in front of politicians and not on TV, but at the meeting of the Valdai Club, where the goal is to improve Russia's image in the international arena" ${ }^{15}$ ).

However, despite the conceptual importance of the President's theses, they will never become a turning point for the country until they resonate with the hearts and minds of the people or at least the most representative socio-demographic groups. Perhaps, this could happen in the Soviet period ${ }^{16}$, but at present the population actively participates in the interaction between the authorities and society (one of the few positive "legacies" of the post-Soviet period). Vladimir Putin's Munich Speech is an excellent proof that if the society is worried about economic problems, then ideology fades into the background.

The scientific and political community immediately noted the conceptual character of Vladimir Putin's Valdai Speech.

\footnotetext{
${ }_{15}$ Avtory "Pereloma" kommentiruyut valdaiskuyu rech" Putina [The Authors of The Breaking Point Comment on Vladimir Putin's Valdai Speech]. Available at: http:// www.rodon.org/society-131007122213

${ }^{16}$ In particular, commenting upon Vladimir Putin's Valdai Speech, V. Tretyakov, one of the authors of the book "The breaking point", said: "The President's speech is not a report of the General Secretary of the CPSU. In the Soviet times each such report was seen as a crucial document, the work of the party and the life of the country were "adjusted" to suit the report. But currently we have democracy, which, however, is more like anarchy". Available at: http://www.rodon.org/ society-131007122213
} 
Figure 3. Dynamics of the level of approval of the performance of the President of the Russian Federation by the residents of the Russian Federation and the Vologda Oblast ( $\%$ of the number of respondents)

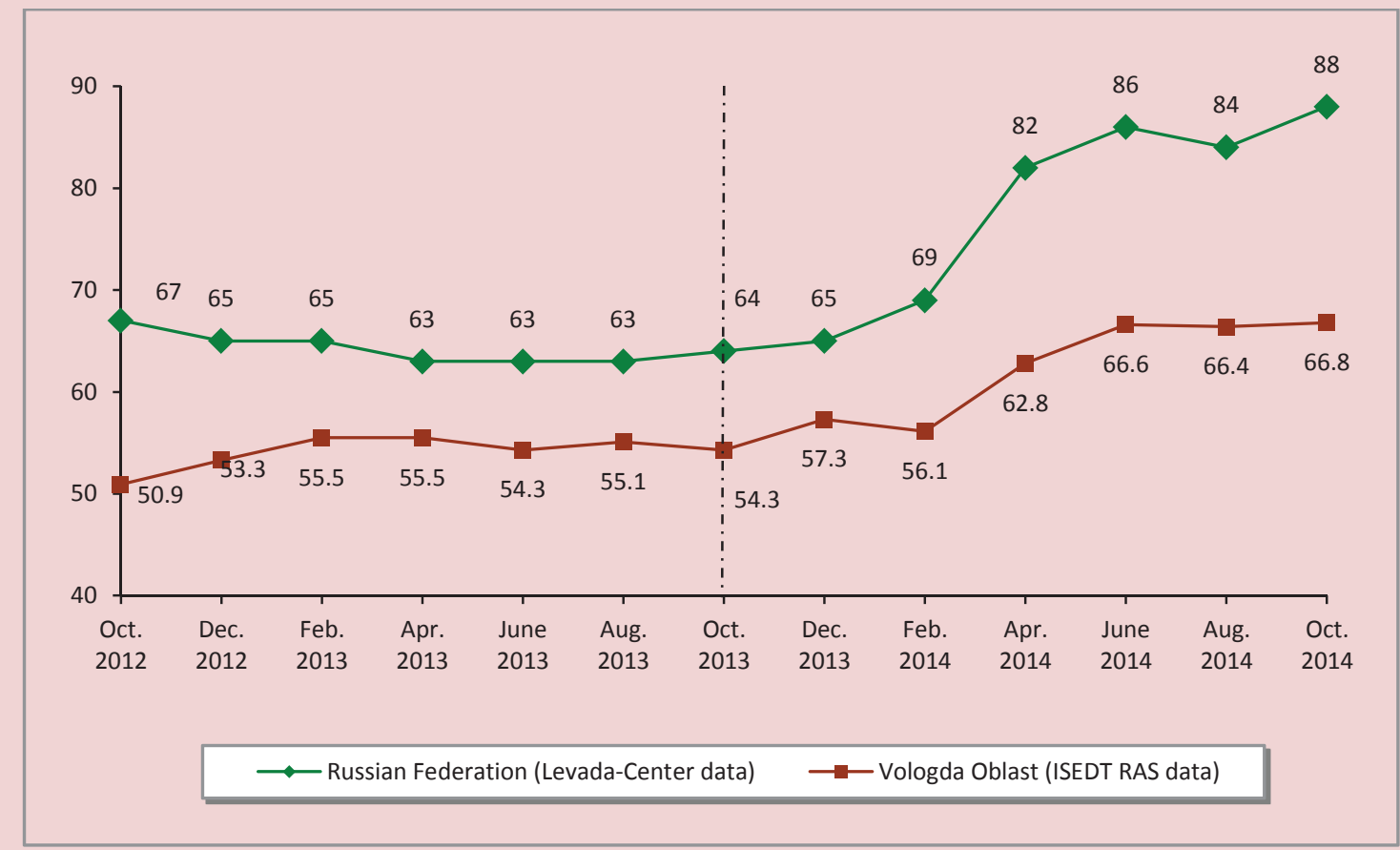

* The graph presents the data for the periods: October 2012 - October 2013 and October 2013 - October 2014, i.e. for six surveys before and after the Valdai Speech of Vladimir Putin.

As for the Russian society in general, it required some time to realize it; and a sequence of events in 2014 (Olympic Games, Ukrainian crisis) served as a "catalyst" for this realization. This is evident in the dynamics of public attitudes toward the performance of the President of the Russian Federation (fig. 3). Nevertheless, the essence of the "new stage" of Russia's history and its foundation were laid in September 2013.

It is noteworthy that the rates of positive trends in the approval of the President have significantly increased after September 2013 in all socio-demographic categories of the population.
For the period from October 2012 to October 2013, i.e. for twelve months before Vladimir Putin's Valdai Speech, the maximum growth of the level of approval of the President's performance amounted to ten percentage points (this was noted only among the poorest $20 \%$ of the Oblast residents). Positive changes were noted in 7 out of 14 categories of the population ${ }^{17}$, while positive dynamics was absent in 7 categories.

For the period from October 2013 to October 2014, after the RF President

${ }^{17}$ In accordance with the methodology of the study, the sampling error does not exceed $3 \%$, so that changes by less than 3 percentage points was not taken into account. 
Table 1. Dynamics of the level of approval of the performance of the President of the Russian Federation in different socio-demographic categories of the Vologda Oblast population (in \% of the number of respondents)

\begin{tabular}{|c|c|c|c|c|c|c|c|c|c|c|c|c|c|c|c|}
\hline \multirow[b]{2}{*}{ Category of population } & \multirow{2}{*}{$\begin{array}{l}\text { Oct. } \\
12\end{array}$} & \multirow{2}{*}{$\begin{array}{c}\text { Dec. } \\
12\end{array}$} & \multirow{2}{*}{$\begin{array}{c}\text { Feb. } \\
13\end{array}$} & \multirow{2}{*}{$\begin{array}{c}\text { Apr. } \\
13\end{array}$} & \multirow{2}{*}{$\begin{array}{c}\text { June } \\
13\end{array}$} & \multirow{2}{*}{$\begin{array}{c}\text { Aug. } \\
13\end{array}$} & \multirow{2}{*}{$\begin{array}{l}\text { Oct. } \\
13\end{array}$} & \multirow{2}{*}{$\begin{array}{c}\text { Dec. } \\
13\end{array}$} & \multirow{2}{*}{$\begin{array}{c}\text { Feb. } \\
14\end{array}$} & \multirow{2}{*}{$\begin{array}{c}\text { Apr. } \\
14\end{array}$} & \multirow{2}{*}{$\begin{array}{c}\text { June } \\
14\end{array}$} & \multirow{2}{*}{$\begin{array}{c}\text { Aug. } \\
14\end{array}$} & \multirow{2}{*}{$\begin{array}{c}\text { Oct. } \\
14\end{array}$} & \multicolumn{2}{|c|}{ Dynamics (+ / -) } \\
\hline & & & & & & & & & & & & & & $\begin{array}{l}\text { Oct. } 13 \text { to } \\
\text { Oct. } 12\end{array}$ & $\begin{array}{l}\text { Oct. } 14 \text { to } \\
\text { Oct. } 13\end{array}$ \\
\hline \multicolumn{16}{|c|}{ Sex } \\
\hline Men & 47.7 & 49.2 & 53.1 & 54.3 & 53.5 & 53.1 & 48.1 & 52.5 & 55.4 & 58.7 & 65.5 & 63.4 & 62.9 & 0 & +15 \\
\hline Women & 53.4 & 56.6 & 57.5 & 56.5 & 54.9 & 56.8 & 59.3 & 61.1 & 56.6 & 66.1 & 67.5 & 68.8 & 69.9 & +6 & +11 \\
\hline \multicolumn{16}{|c|}{ Age } \\
\hline Under 30 & 50.8 & 50.1 & 55.6 & 56.6 & 48.1 & 50.9 & 53.4 & 52.7 & 53.0 & 61.1 & 63.4 & 68.8 & 67.9 & +3 & +15 \\
\hline $30-55$ & 48.2 & 54.3 & 53.0 & 53.5 & 57.7 & 57.3 & 54.1 & 56.5 & 54.9 & 62.4 & 67.3 & 61.8 & 67.3 & +6 & +13 \\
\hline Over 55 & 55.1 & 54.5 & 59.5 & 57.9 & 53.6 & 55.1 & 55.1 & 61.6 & 59.8 & 64.7 & 67.7 & 71.4 & 65.5 & 0 & +10 \\
\hline \multicolumn{16}{|c|}{ Education } \\
\hline $\begin{array}{l}\text { Incomplete secondary, } \\
\text { secondary }\end{array}$ & 47.1 & 44.2 & 52.0 & 50.1 & 51.6 & 51.1 & 47.5 & 55.8 & 51.9 & 58.1 & 60.0 & 60.0 & 56.2 & 0 & +9 \\
\hline Secondary vocational & 51.8 & 54.8 & 55.9 & 57.1 & 55.2 & 54.2 & 54.3 & 58.1 & 58.0 & 62.1 & 68.6 & 68.7 & 72.4 & +3 & +18 \\
\hline $\begin{array}{l}\text { Incomplete higher, } \\
\text { higher }\end{array}$ & 53.5 & 59.9 & 58.6 & 59.7 & 56.3 & 60.1 & 61.4 & 58.2 & 58.8 & 69.2 & 72.0 & 70.6 & 73.1 & +8 & +12 \\
\hline \multicolumn{16}{|c|}{ Income groups } \\
\hline $\begin{array}{l}20 \% \text { of the poorest } \\
\text { people }\end{array}$ & 40.7 & 36.6 & 40.9 & 43.4 & 52.8 & 47.0 & 50.7 & 62.7 & 46.1 & 48.9 & 54.6 & 59.7 & 57.3 & +10 & +7 \\
\hline $\begin{array}{l}60 \% \text { of the people with } \\
\text { middle-sized income }\end{array}$ & 53.0 & 55.1 & 59.2 & 58.2 & 53.9 & 54.3 & 54.4 & 56.4 & 57.9 & 64.4 & 69.4 & 67.0 & 69.0 & +1 & +15 \\
\hline $\begin{array}{l}20 \% \text { of the most } \\
\text { prosperous people }\end{array}$ & 59.3 & 66.0 & 63.9 & 64.9 & 60.8 & 66.7 & 60.8 & 64.6 & 69.4 & 72.6 & 77.7 & 78.0 & 76.8 & +2 & +16 \\
\hline \multicolumn{16}{|c|}{ Territories } \\
\hline Vologda & 54.0 & 53.4 & 51.5 & 54.7 & 51.1 & 54.1 & 52.7 & 55.2 & 53.1 & 61.0 & 66.6 & 65.3 & 65.2 & -1 & +13 \\
\hline Cherepovets & 61.5 & 63.2 & 64.1 & 61.4 & 65.3 & 62.8 & 63.8 & 65.0 & 66.8 & 73.2 & 74.4 & 77.8 & 81.3 & +2 & +18 \\
\hline Districts & 44.3 & 48.3 & 53.1 & 52.8 & 49.9 & 51.5 & 49.8 & 54.1 & 51.8 & 58.1 & 62.3 & 60.7 & 59.8 & +6 & +10 \\
\hline Average for the Oblast & 50.9 & 53.3 & 55.5 & 55.5 & 54.3 & 55.1 & 54.3 & 57.3 & 56.1 & 62.8 & 66.6 & 66.4 & 66.8 & +3 & +13 \\
\hline
\end{tabular}

delivered his speech at the meeting of the Valdai International Discussion Club, the maximum increase in the approval of V. Putin's performance was 18 percentage points (among the persons with secondary vocational education and the residents of Cherepovets). Obvious positive changes were noted in all the socio-demographic groups. In 10 out of the 14 groups the support to the head of state increased by more than 10 percentage points (tab. 1).
It is important to point out objective circumstances, which predetermined that Putin's Valdai Speech would become, if not the beginning, then, at least, one of the most important events in the formation of a new phase of the Russian history. For the first time it was the time factor, which, as it turned out, decides if not everything, but, at least, very much: if the 2007 Munich Speech of the President of the Russian Federation was followed by 
the global financial crisis, then after his Valdai Speech public attention was focused on the Olympic Games, the accession of Crimea and Sevastopol to Russia, the oppression of Russian-speaking population in Ukraine; and even the policy pursued by the U.S. and its supporting countries fit perfectly into the vision of the world order that was outlined by President Putin in September 2013.

The idea of the revival of the "Russian world" and restoration of Russia's status as one of the main centers of a multipolar world order has found considerable support in the Russian society, and not only because the President's Valdai Speech was followed by events which brought together various strata of the population, and united people with different opinions around the figure of the head of state. No less it was affected by the past Russian history, namely:

a) the fact of existence of the Soviet Union;

b) the fact of its collapse, followed by a period of the "turbulent 1990s";

c) the fact of a nearly 10-year period (2000-2010), when the society was recovering after the radical break of ideological direction of development and socio-economic transformations.

The Soviet Union provided the modern Russian society with the memories of social protection mechanisms of the state that were actually working, with the outstanding achievements in science, sport and art. Indeed, it is not a coincidence that even nowadays the most important movies for an average Russian remain those that belong to the Soviet (not Russian) cinema; they have even become part of national holidays.

The Soviet Union gave the modern Russian society an opportunity to compare two completely different periods, and the choice of the Russians is more and more often not in favor of the post-Soviet Russia $^{18}$.

The 1990s have shown that the Western democracy is alien to the Russian people and unacceptable for them. The same can be also said about the values of the Western world and its form of government.

Although it seems that the period of 2000-2010 has not brought such large-scale transformations into the Russian history as the previous eras, it was, in fact, also very important. It provided the Russian society with an opportunity to adapt to changing conditions, to understand them, to realize what the people really want, and, finally, to accumulate the critical mass in anticipation of change and in the willingness to revise the established (or, rather, not established) system of values.

18 Although this has its disadvantage: if the changes that took place in the 1990s would provide the Russian society with the best specimens of the Western experience to solve social problems, rather than what has ultimately happened, then perhaps today the Russians would have a broader view of the events - when assessing the existing state of affairs in the country and their lives, they would make comparisons not only by looking back, but by looking around, i.e. not only along the line of "USSR Russia", but also along the line "Russia - Europe". Is this the fault of the reformers of the 1990s? Or was the collapse of the USSR one of the goals of the United States? Or both? It does not matter in the context of this article. We would like to emphasize the fact that today, an average Russian assessing his/her life will surely add: "It used to be different" and under that "used to be" he/she will mean exclusively the Soviet period. 
The stabilization of the political and economic situation in the country, growth of the standard of living, termination of disastrous trends in the demographic situation - all this has blocked the acute problems that threaten national security (we do not use the word "solved", but "blocked the acuteness"). The satisfaction of vital needs was followed by the growth of the needs of a higher level: better quality of life, social justice, national identity, confidence in the future.

Thus, the three above-mentioned circumstances and the three periods in the history of post-Soviet Russia have led to the fact that by the late 2000s the Russian society has formed the needs for the following:

a) strong state power;

b) the feeling of pride for Russia;

b) intangible, spiritual values.

It is the mechanism of implementation of these three kinds of needs that was outlined in Vladimir Putin's Valdai Speech.

Therefore, we can and must speak of a new stage in the Russian history. It has its own specific characteristics that distinguish it from other stages of the post-Soviet period. The question is how long it will last and what it eventually will lead to... The new stage in the Russian history has its own distinctive features.

\section{Strong state power.}

Studying the specifics of "Russian dream", the specialists at the Institute of Sociology of the Russian Academy of Sciences have come to the conclusion that an ideal model of state structure, in the opinion of the Russians, is based on three "pillars": social justice, equal rights for all, and the strong state that cares about its citizens ${ }^{19}$.

Several scientists (Yu.V. Kosov, A.L. Andreev, and others) believe that the tendency toward authoritarian leadership style is a feature of the Russian mentality. In part we agree with that. Historically Russia has always gravitated toward autocracy; in this regard, the very institution of the presidency possesses an element of tradition, being in this way somewhat similar to the monarchic form of government. Due to this feature, the Russian system of government differs from Oriental despotism, or Western democracy ${ }^{20}$. Moreover, the political consciousness of the people attaches the prime importance not to how the country is governed, but to the leader it is governed by. In other words, it is not the leader that fits into the system, but it is the system that adapts to the leader. Such Russian system of democracy does not resemble that of Washington or Berlin; but, ironic as it might be, it is the only effective and actually working institute for modern Russia ${ }^{21}$.

\footnotetext{
${ }^{19}$ Gorshkov M.K. "Russkaya mechta": opyt sotsiologicheskogo izmereniya [A "Russian Dream": the Experience of Sociological Assessment]. Sotsiologicheskie issledovaniya [Sociological Studies], 2012, no. 12, p. 7.

${ }^{20}$ Zuikov A.V. Institut prezidentstva v Rossii: konstitutsionnaya model', sovremennye realii i perspektivy razvitiya [The Institution of the Presidency in Russia: the Constitutional Model, Current Realities and Prospects]. Konstitutsionnyi vestnik [Constitutional Herald], 2008 , no. 1(19), p. 171.

${ }^{21}$ Tret'yakov V.T. Doklad na kruglom stole "Institut prezidentstva $v$ Rossii: pravovye osnovy i rol'v modernizatsii obshchestva” 8 iyunya 2011 g. [The Round Table Report "The Institution of the Presidency in Russia: Legal Basis and Role in the Modernization of Society", June 8, 2011]. Available at: http://education.law-books.ru/index. php? page $=$ kruglyj-stol
} 
We can have long discussions about the separation of powers, dwelling on the peculiarities of their mutual deterrence and balance, but we will always keep in mind that our country has a constitutional institution, which stands above these democratic "games" and, in fact, defines the vector of development of modern Russia ${ }^{22}$.

Opinion polls carried out by ISEDT RAS clearly demonstrate that mental specifics of the Russian society that are expressed in high level of trust in the institutions "traditional" for Russian mentality - the government and the Church (primarily, the head of state), has not disappeared over the past 15 years.

In this respect, the personality of Vladimir Putin, no doubt, plays an important role in the attitude of the population toward the head of state (judging by the decrease in the level of trust in the President during the period when this post was held by Dmitry Medvedev, from May 2008 to May 2012; tab. 2), but even at this time people's trust in the President was higher than in all other state and public institutions.

Mentality is one, but not the only reason why the Russian society favors a strong state power. As a feature of a new stage in the Russian history, it originated due to, let us put it mildly, certain unsuccessful actions of Russian reformers in the 1990s.

${ }^{22}$ Sil'vestrov S.N. Doklad na kruglom stole "Institut prezidentstva $v$ Rossii: pravovye osnovy i rol'v modernizatsii obshchestva" 8 iyunya 2011 g. [The Round Table Report "The Institution of the Presidency in Russia: Legal Basis and Role in the Modernization of Society", June 8, 2011]. Available at: http://education.law-books.ru/index. php?page $=$ kruglyj-stol
According to some scholars, the assumption that the liberal reforms in the 1990s failed due to mentality-related reasons is absolutely inconsistent; it is proved by the experience of Japan, South Korea, China, Taiwan, Malaysia and other Asian, South American and some African countries $^{23}$. Peoples of different cultures and mentalities demonstrate outstanding achievements in economy. Therefore, it is of crucial importance that the specifics of national mentality are not an obstacle to achieving socio-economic progress ${ }^{24}$.

The discrediting of democracy and the creation of actual prerequisites for authoritarianism are the main sociopolitical results of the activities of the Russian reformers ${ }^{25}$. The process democratization that was launched on unprepared foundations, caused, as was to be expected judging by the past experience of several countries, sharp disparities in all the spheres of the society. In these circumstances the principle of "everything

${ }^{23}$ Simonyan R.Kh. Est' li osobyi "russkii put"”? (polemicheskie zametki) [Is There a Special "Russian Way"? (Polemical Notes)]. Sotsis [Sociological Studies], 2013, no. 7, p.139.

${ }^{24}$ Yadov V.A. Sovremennaya teoreticheskaya sotsiologiya kak kontseptual'naya baza issledovaniya rossiiskikh transformatsii: Kurs lektsii dlya studentov magistratury po sotsiologii. Izd. vtoroe, ispravl. i dopoln. [Modern Theoretical Sociology as a Conceptual Framework of the Research on Russian Transformations: a Course of Lectures for Master's Degree Students in Sociology]. Second edition, revised and supplemented. Saint Petersburg: Intersotsis, 2009. 138 p. Available at: http://www.isras.ru/ index.php?page_id=1330\&id=1393\&param=http://www. isras.ru/files/File/Publication/Sovremennaya_teoret_ sociol_2009_Yadov.pdf

${ }^{25}$ Simonyan R.Kh. Est' li osobyi "russkii put"”? (polemicheskie zametki) [Is There a Special "Russian Way"? (Polemical Notes)]. Sotsis [Sociological Studies], 2013, no. 7, p. 143. 
A new stage of Russian history: trends, specifics and prospects

Table 2. Level of trust in the state and public institutions (in \% of the number of respondents)*

\begin{tabular}{|c|c|c|c|c|c|c|c|c|c|c|c|c|c|}
\hline Institution & 2000 & 2003 & 2005 & 2006 & 2007 & 2008 & 2009 & 2010 & 2011 & 2012 & 2013 & 2014 & $\begin{array}{l}\text { Average for } \\
2000-2014\end{array}$ \\
\hline RF President & 57.1 & 64.3 & 57.7 & 62.0 & 60.3 & 65.2 & 51.6 & 56.8 & 50.5 & 45.7 & 47.0 & 57.0 & 56.3 \\
\hline RF Government & 42.7 & 42.7 & 38.0 & 42.1 & 41.9 & 60.2 & 46.7 & 52.4 & 47.4 & 39.6 & 40.4 & 48.3 & 45.2 \\
\hline Federation Council & 28.3 & 34.9 & 30.4 & 34.3 & 34.9 & 47.6 & 35.9 & 38.1 & 35.5 & 32.3 & 34.6 & 40.2 & 35.6 \\
\hline State Duma & 23.0 & 27.9 & 27.1 & 27.9 & 29.5 & 42.0 & 33.5 & 33.5 & 32.0 & 30.5 & 31.6 & 35.2 & 31.1 \\
\hline RF Public Chamber** & n.a. & n.a. & n.a. & n.a. & n.a. & n.a. & n.a. & 27.3 & 27.3 & 28.1 & 29.9 & 32.8 & 29.1 \\
\hline $\begin{array}{l}\text { Vologda Oblast } \\
\text { Government }\end{array}$ & 31.3 & 31.9 & 32.8 & 37.7 & 40.6 & 48.6 & 34.9 & 41.0 & 36.6 & 34.6 & 37.8 & 37.4 & 37.1 \\
\hline Local Government** & n.a. & n.a. & n.a. & 26.6 & 32.3 & 40.9 & 33.1 & 35.6 & 33.9 & 29.3 & 32.7 & 35.1 & 33.3 \\
\hline $\begin{array}{l}\text { Vologda Oblast Public } \\
\text { Chamber** }\end{array}$ & n.a. & n.a. & n.a. & n.a. & n.a. & n.a. & n.a. & 24.8 & 25.7 & 25.4 & 29.2 & 29.4 & 26.9 \\
\hline Police & 27.2 & 25.7 & 27.1 & 29.0 & 28.3 & 36.5 & 33.1 & 32.7 & 32.1 & 29.3 & 33.7 & 35.4 & 30.8 \\
\hline $\begin{array}{l}\text { Federal Security } \\
\text { Service }\end{array}$ & 34.2 & 34.9 & 35.6 & 35.3 & 34.2 & 43.8 & 34.3 & 36.0 & 35.8 & 33.2 & 37.5 & 36.4 & 35.9 \\
\hline Court & 31.6 & 31.3 & 36.9 & 35.5 & 32.1 & 41.3 & 35.1 & 37.4 & 35.8 & 36.1 & 39.3 & 36.9 & 35.8 \\
\hline Procuracy & 30.9 & 28.8 & 34.3 & 33.3 & 31.1 & 40.9 & 34.8 & 36.1 & 35.4 & 33.9 & 40.1 & 38.5 & 34.8 \\
\hline Army & 37.0 & 30.9 & 25.9 & 29.6 & 28.7 & 37.8 & 33.5 & 34.5 & 34.1 & 31.3 & 37.5 & 37.8 & 33.2 \\
\hline Trade Unions & 28.4 & 24.7 & 27.9 & 27.4 & 28.6 & 35.9 & 28.1 & 29.9 & 30.0 & 25.6 & 27.8 & 26.6 & 28.4 \\
\hline Church & 42.3 & 45.9 & 46.5 & 42.9 & 44.8 & 51.9 & 44.9 & 47.0 & 47.5 & 41.4 & 43.9 & 44.7 & 45.3 \\
\hline Public organizations ** & n.a. & n.a. & n.a. & 20.0 & 24.4 & 32.6 & 23.8 & 26.7 & 26.7 & 26.5 & 26.8 & 25.5 & 25.9 \\
\hline $\begin{array}{l}\text { Political parties, } \\
\text { movements }\end{array}$ & 20.4 & 10.6 & 17.4 & 16.0 & 17.8 & 17.6 & 26.8 & 20.0 & 22.8 & 22.8 & 20.9 & 20.2 & 19.4 \\
\hline Mass Media & 30.2 & 21.6 & 27.3 & 30.4 & 31.0 & 27.5 & 35.2 & 28.7 & 29.2 & 28.7 & 29.5 & 28.0 & 28.9 \\
\hline Directors, CEOs & 19.6 & 24.1 & 23.6 & 26.5 & 23.6 & 30.5 & 22.5 & 22.8 & 22.3 & 25.1 & 27.5 & 21.9 & 24.2 \\
\hline Banks, entrepreneurs & 12.4 & 19.5 & 20.6 & 22.6 & 21.3 & 26.6 & 20.3 & 21.5 & 20.4 & 21.3 & 23.4 & 18.8 & 20.7 \\
\hline
\end{tabular}

which is not forbidden by law is allowed" has played the same role, as it had played in the French Revolution. The state did not have a sufficient legal framework to prevent the surge of corruption and domestic crime $^{26}$.

${ }^{26}$ Kalina F.V., Kurskova G.Yu. Sotsiologiya zakonodatel'stva i pravotvorcheskii protsess [Sociology of Law and the Law-Making Process]. Yurisprudentsiya [Jurisprudence], 2003, no. 1. Available at: http:// pravorggu.ru/2004_2/15kalina-kurskova-sotsiologiya_ zakonodatelstva_13.shtml
The fact that liberal forces do not gain much support in public opinion is clearly evidenced in the results of sociological surveys (studying the electoral preferences of the population), and official statistics (the results of elections after 2000). According to VTSIOM, the proportion of Russians who support right-wing parties ("Yabloko", "Soyuz pravykh sil" (The Union of Right Forces)), since 2000 has not exceed $7 \%$ and $9 \%$, respectively, and 
Table 3. How successfully, in your opinion, does the President of the Russian Federation cope with the following problems..? (in \% of the number of respondents)

\begin{tabular}{|c|c|c|c|c|c|c|c|c|c|c|c|c|c|}
\hline \multirow{2}{*}{ Indicator } & \multirow{2}{*}{2000} & \multirow{2}{*}{2003} & \multirow{2}{*}{2005} & \multirow{2}{*}{2007} & \multirow{2}{*}{2008} & \multirow{2}{*}{2009} & \multirow{2}{*}{2010} & \multirow{2}{*}{2011} & \multirow{2}{*}{2012} & \multirow{2}{*}{2013} & \multirow{2}{*}{2014} & \multicolumn{2}{|c|}{ Dynamics, $2014+/-$ to } \\
\hline & & & & & & & & & & & & 2000 & 2013 \\
\hline \multicolumn{14}{|c|}{ Strengthening Russia's international standing } \\
\hline Successful & 42.3 & 44.9 & 47.9 & 58.4 & 55.1 & 49.5 & 49.9 & 46.2 & 43.1 & 45.6 & 50.4 & +8 & +5 \\
\hline Unsuccessful & 30.9 & 30.1 & 33.8 & 24.9 & 23.7 & 30.4 & 29.3 & 33.7 & 37.9 & 36.2 & 32.4 & +2 & -4 \\
\hline \multicolumn{14}{|c|}{ Imposing order in the country } \\
\hline Successful & 31.4 & 37.5 & 41.9 & 53.2 & 48.2 & 39.1 & 41.1 & 36.6 & 35.4 & 39.4 & 48.0 & +17 & +9 \\
\hline Unsuccessful & 49.2 & 45.1 & 45.1 & 34.0 & 34.2 & 43.5 & 42.5 & 50.0 & 50.7 & 47.5 & 39.1 & -10 & -8 \\
\hline \multicolumn{14}{|c|}{ Protecting democracy and strengthening the citizens' freedoms } \\
\hline Successful & 23.5 & 29.9 & 33.6 & 44.4 & 39.9 & 36.7 & 36.3 & 32.4 & 28.8 & 31.8 & 37.5 & +14 & +6 \\
\hline Unsuccessful & 43.8 & 42.4 & 47.0 & 37.0 & 35.9 & 41.5 & 42.6 & 48.3 & 52.3 & 51.0 & 45.4 & +2 & -6 \\
\hline \multicolumn{14}{|c|}{ Economic recovery and increase in the citizens' welfare } \\
\hline Successful & 25.6 & 29.6 & 35.1 & 47.2 & 36.7 & 31.6 & 33.5 & 30.7 & 28.5 & 31.3 & 34.8 & +9 & +4 \\
\hline Unsuccessful & 52.9 & 51.4 & 50.8 & 39.1 & 46.0 & 52.4 & 51.6 & 56.1 & 57.9 & 56.8 & 53.4 & +1 & -3 \\
\hline
\end{tabular}

since 2005 - only $2 \%$. According to ISEDT RAS data, the share of the Oblast residents, whose interests are expressed by the party "Yabloko", for the same period has not exceeded 5\%. According to the Central Election Commission of the Russian Federation, at the elections to the State Duma in 2003, 2007 and 2011, the rightwing parties gained less than $4 \%$ of votes, and their candidates at the presidential elections in 2000, 2004, 2008 and 2012 gained not more than $8 \%$ of votes ${ }^{27}$.

Thus, the demand for strong power in the Russian society is a logical consequence of "fatigue" that the population feels due to economic instability and distrust in the state. Strong power was needed in the early 2000s, and this remains relevant today as well. It is no coincidence that the activity

\footnotetext{
${ }^{27}$ Data of the Central Election Commission of the Russian Federation. Available at: http://www.vybory. izbirkom.ru/region/izbirkom
}

of President Putin aimed to restore order in the country and strengthen the international position of Russia has always been assessed higher than the defense of democracy and strengthening of civil liberties ( $t a b .3)$. And it is no coincidence, that one third of the Russians respect Joseph Stalin, although three years ago this attitude was expressed only by $21 \%$ of the respondents; $45 \%$ of the Russians believe that the sacrifices made by the Soviet people in the Stalin era were justified by the great goals and the results achieved in the shortest possible time (in 2012 there were $25 \%$ of those who thought that way); the idea of erecting a monument to Stalin in 2010 was approved by $24 \%$ of Russians, and in 2015 - by $37 \%^{28}$.

${ }^{28}$ Vse bol'she rossiyan polozhitel'no otnosyatsya k Stalinu [More and More Russians Have a Positive Attitude towards Stalin]. Vedomosti [The News], March 30, 2015. Available at: http://www.vedomosti.ru/politics/ articles/2015/03/31/vse-bolshe-rossiyan-polozhitelnootnosyatsya-k-stalinu-levada-tsentr 
What is the main feature of strong power today? Why do we consider it an attribute of the new stage? Indeed, we all know that strong power and an outstanding leader, and authoritarian (and sometimes even totalitarian) form of government was a common thing in the Russian history.

The reason is that strong power today is not only a single ideological concept at all the levels of public administration, not just a single clear strategy of action, but it is also the unity with public opinion. In other words, strong power can not but pay attention to the needs of the society that made it legitimate. The people begin to play an increasingly prominent role in public and political life. The power of the authorities today has a qualitatively different foundation compared to, for example, the Soviet period or tsarist Russia, and this is a specific sign of a new stage of the postSoviet history, with which its second and third attributes are closely linked - the effectiveness of public administration and the relevance of intangible factors in development.

\section{Public administration efficiency.}

At the meeting on the implementation of the decrees of May 7, 2012 the RF President Vladimir Putin outlined the strategy for changes and the target guidelines of state policy to be achieved by 2018. The President pointed out: "The overall objective of this work is to create new and higher standard of living for the citizens of the Russian Federation, primarily by substantially improving the efficiency of public administration and the state's performance" 29 . In his subsequent speeches, the President has shown his commitment to implement the outlined strategy, despite negative processes going on in the global economy and the unstable international political situation.

The goal to enhance the efficiency of public administration is an attribute, which stems directly out of the demand for a strong state power. Its origins come not only from the reforms of the 1990s, but from the period of "stabilization" of the 2000s; these origins include the lingering unresolved key problems of the country: dependence of the Russian economy on raw material resources, lack of competitiveness of domestic producers, high level of population differentiation by income level, low level of development of civil society, etc.

The oligarchic and corrupt power "vertical" created in the 2000s was a major obstacle to successful and closer cooperation between Russia and advanced countries of the West. The activities of this vertical lead to the redistribution of major resources from the groups focused on the modernization of the society to the top that strives for limitless personal enrichment. Under these conditions, the modernization of the Russian society involves not only and not so much the development of new technologies, but the formation of a strong,

${ }^{29}$ Putin V.V. Rech' na soveshchanii o khode ispolneniya ukazov Prezidenta 7 maya 2012 goda [Speech at the Meeting on the Implementation of the Presidential Decrees of May 7, 2012]. Ofitsial'nyi sait Prezidenta $R F$ [Official Website of the President of the Russian Federation]. Available at: http://www.kremlin. $\mathrm{ru} /$ news/18039 
competent legal and legitimate authority capable of radical democratization and strengthening of key public institutions ${ }^{30}$.

However, it would be wrong to say that in all other periods of the Russian history the state did not care about improving the efficiency of management. In different times this care took different forms. The specificity of the present stage consists in the fact that now it is much harder to implement this care, because the society itself participates in the assessment of this work as an active and, perhaps, the principal, subject. 2014 has shown that the state and society in Russia are not opposites, but partners in the common goal of developing their country ${ }^{31}$.

Satisfaction of the population becomes the main sign that shows the performance efficiency of state power. During the "direct line" with the population in April 2013, Vladimir Putin pointed out: "It is necessary to make sure that all the leaders of any rank: in the presidential structures and in the Government feel and understand that ordinary citizens are closely watching the results of our work and give their assessments thereof. It is necessary to be guided by the opinion of the citizens... Our general efficiency and competitiveness, no

\footnotetext{
${ }^{30}$ Materialy IV Vserossiiskogo sotsiologicheskogo kongressa "Sotsiologiya i obshchestvo: global'nye vyzovy i regional'noe razvitie" [Proceedings of the 4th All-Russian Sociological Congress "Sociology and Society: Global Challenges and Regional Development]. Ofitsial'nyi sait Rossiiskogo obshchestva sotsiologov [Official Website of the Russian Society of Sociologists]. Available at: http://www. ssa-rss.ru/files/File/congress2012/part3.pdf

${ }^{31}$ Doklad o sostoyanii grazhdanskogo obshchestva $v$ Rossiiskoi Federatsii za 2014 god [Report on the State of Civil Society in the Russian Federation for 2014]. Available at: http://www.oprf.ru/documents/1151/
}

doubt, depends on the degree of people's trust in the actions of the authorities" 32 .

The increased role of public opinion in assessing the effectiveness of government is largely associated with the third attribute of the new time - the relevance of intangible factors of development.

\section{Relevance of intangible development factors.}

After the 20-year period of the postSoviet Russia and all the twists and turns that the Russian society went through during that time, it is impossible to speak of Russia as a totalitarian country, and of the President of the Russian Federation as the top person of the state, who possesses unlimited power and slights public opinion (this exactly what the Western mass media often try to do). It is not even possible to restore a strict power vertical characteristic of the Soviet period, because "we have abandoned the Soviet ideology, it is impossible to return it" ${ }^{33}$, "the post-Soviet stage in the development of Russia, as well as in the development of the whole world, is completed and exhausted" 34 .

${ }^{32}$ Stenogramma "Pryamoi linii" s Prezidentom RF V.V. Putinym ot 25.04.2013 [Transcript of "Direct Line" with Russian President Vladimir Putin, April 25, 2013]. Rossiiskaya Gazeta [Russian Newspaper]. Available at: http://www.rg.ru/2013/04/25/stenogramma-site.html

${ }_{33}$ Stenogramma vystupleniya V. Putina na zasedanii mezhdunarodnogo diskussionnogo kluba «Valdai» 19.09.2013 [Transcript of V. Putin's Speech at the Session of the Valdai International Discussion Club]. Rossiiskaya gazeta [Russian Newspaper], September 19, 2013. Available at: http://www.rg.ru/2013/09/19/stenogrammasite.html

${ }^{34}$ Putin V.V. Rossiya sosredotachivaetsya - vyzovy, na kotorye my dolzhny otvetit' [Russia Muscles Up the Challenges We must Rise to Face] Izvestiya [News], January 16, 2012. Available at: http://izvestia.ru/ news $/ 511884$ 
Vladimir Putin's frequent statements that public opinion today is the main indicator of public administration efficiency; the "direct line" with the President; his meeting with representatives of science, which indicate his interest in their opinion; the relevance of sociological knowledge and, accordingly, the reviving domestic sociology, which "over a short period of time has been developed in all the regions of our country" 35 ; the intensification of various forms of interaction between the representatives of regional and municipal authorities and the population; the increased status of public organizations (Public Chamber, All-Russia People's Front, etc.) - these are the signs of a new time and the evidence that today the society is one of the main subjects that make Russian history.

The desire of the President of the Russian Federation "to change Russia qualitatively, to feel people's mood and support, to be on the same wavelength with these sentiments, to unite them and to make breakthroughs that the society expects of him" 36 was one of the motives and prerequisites for the institutional formation of the All-Russia People's Front.

${ }^{35}$ Osipov G.V. Vystuplenie na IV Vserossiiskom sotsiologicheskom Kongresse "Sotsiologiya v sisteme nauchnogo upravleniya obshchestvom" 2 fevralya 2012 g. [Speech at the 4th All-Russian Sociological Congress "Sociology in the System of Scientific Management of Society", February 2, 2012]. Press-reliz IV Vserossiiskogo sotsiologicheskogo kongressa [Press Release of the 4th AllRussian Sociological Congress]. Available at: http://www. isras.ru/index.php?page_id $=1665$

${ }^{36}$ Migranyan A.M. Narod i lider nashli drug druga [The People and the Leader have Found Each Other]. Gazeta "Izvestiya" [The News], June 12, 2013. Available at: http://izvestia.ru/news/551898
The relevance of intangible development factors as a feature of a new phase of the post-Soviet Russia consists not only in the consequences of the collapse of the Soviet Union and penetration of Western democratic notions into the system of spiritual and moral values of the Russians. The underlying cause of enhancing the role of public consciousness and behavior in the matters related to the economy and form of government lies in the fact that this is the natural course of evolution. The regime, which is totalitarian in its essence (no matter what name it "hides" behind), cannot manage a complex and highly developed society, unless there are individual circumstances of force majeure, which are often temporary (e.g., war). As the complexity of social relations increases and the progress in science and technology moves forward, the public consciousness of the people also changes and the number and quality of people's questions to the government increases, and this is not a specific feature of Russian society, but, rather, the natural course of human development.

\section{National identity.}

While analyzing the key attributes of the new stage of Russia's history, we would like to emphasize the fact that due to the growing need for the sense of national pride and the need for national identity, the government has started to solve the problems of a low level of development of civil society and social atomism that were characteristic of the post-Soviet period until 2014. 
It is interesting that many elements of civil society in Russia, strange as it may seem, existed in the late Soviet era: we had created huge reserves of social capital; otherwise, millions of people would not have taken to the streets. We had so many elements of civil society in the late authoritarian era: from clubs of amateur singers to Moscow kitchens, Economic and Mathematical School at the Moscow State University since 1968 and so on. Here, those were the places, where social capital was produced ${ }^{37}$.

Quite a lot has already been said about the problems of civil society and low level of development of social capital after the collapse of the Soviet (E.G. Yasin, V.K. Levashov, A.A. Auzan, R.S. Menyashev, etc.); a lot of studies has been carried out (ISEDT RAS, ISPR RAS, NRU HSE, etc.).

There are many works on the phenomenon of social atomism (S.G. KaraMurza, V.I. Zhukov and others), which can lead to large-scale consequences: "decreasing the level of self-identification of people to elite groups, corporations, friends, family, reducing their interests to selfish purposes of minor communities weakens the integrity of the society. They cease to be the cells of a single state mechanism. In public opinion the very concepts of "state", "fatherland" as the ultimate guarantors of sustainable development and satisfaction of the needs

\footnotetext{
${ }^{37}$ Auzan A.A. Obshchestvennyi dogovor i grazhdanskoe obshchestvo [Social Contract and Civil Society]. Available at: http://polit.ru/article/2005/01/11/auzan/
}

become worthless, and the citizens no longer feel responsible for their fate" ${ }^{38}$.

We will not focus on the analysis of these grave consequences of the collapse of the USSR, which were disastrous for the country's development; however, we consider it important to note that in 2014 there emerged real opportunities to overcome them. The results of sociological research carried out by ISEDT RAS show that in 2014 there was almost a 2-fold increase in the proportion of people who believe that today Russia has "more harmony and cohesion than disagreement and disunity"; the proportion of people who are willing to unite for ideological reasons increased significantly (tab. 4).

The trends of overcoming social atomism and growing civil consciousness are the clear evidence of strengthening national identity resulting from the consolidation of the Russian society around the ideas put forward by Vladimir Putin at the Valdai forum in 2013, and "triggered" by the development of the geopolitical situation in 2014. The development of these positive trends, emerging only in 2014, largely determines further success of the country's moving toward "moral and economic recovery" 39 .

${ }^{38}$ Chuguenko V.M., Bobkova E.M. Novye tendentsii $\mathrm{v}$ issledovanii sotsial'nogo samochuvstviya naseleniya [New Trends in Research on Social Well-Being of the Population]. Sotsiologicheskie issledovaniya [Sociological Studies], 2013, no. 1, p. 23.

${ }^{39}$ Osipov G.V. Ne upustit' predostavivshiisya shans! [Do not Miss This Chance!]. Sotsiologiya i ekonomika sovremennoi sotsial'noi real'nosti. Sotsial'naya i sotsial'nopoliticheskaya situatsiya $v$ Rossii v 2013 godu [Sociology and Economics of the Current Social Reality. Social and Socio-Political Situation in Russia in 2013]. Moscow: ISPI RAN. P. 12. 
Table 4. Data of the opinion polls showing the overcoming of social atomism and the development of civil society (in \% of the number of respondents) ${ }^{*}$

\begin{tabular}{|c|c|c|c|c|c|}
\hline \multirow{2}{*}{ Indicator } & \multirow{2}{*}{2011} & \multirow{2}{*}{2013} & \multirow{2}{*}{2014} & \multicolumn{2}{|c|}{ Dynamics (+ / -) 2014} \\
\hline & & & & to 2013 & to 2011 \\
\hline \multicolumn{6}{|c|}{$\begin{array}{l}\text { In your opinion, is there more harmony and cohesion or disagreement and disunity today? } \\
\qquad \text { (in } \% \text { of the number of respondents) }{ }^{*}\end{array}$} \\
\hline \multicolumn{6}{|c|}{ In our country } \\
\hline More harmony and cohesion & 14.2 & 14.1 & 28.9 & +15 & +15 \\
\hline More disagreement and disunity & 61.1 & 59.5 & 44.1 & -15 & -17 \\
\hline It is difficult to answer & 24.7 & 26.4 & 27.0 & +1 & +2 \\
\hline \multicolumn{6}{|c|}{ In our Oblast } \\
\hline More harmony and cohesion & 19.3 & 15.9 & 26.9 & +11 & +8 \\
\hline More disagreement and disunity & 55.6 & 54.4 & 44.7 & -10 & -11 \\
\hline It is difficult to answer & 25.1 & 29.7 & 28.4 & -1 & +3 \\
\hline \multicolumn{6}{|c|}{ In the your place of residence } \\
\hline More harmony and cohesion & 24.1 & 28.4 & 39.1 & +11 & +15 \\
\hline More disagreement and disunity & 51.5 & 44.3 & 34.3 & -10 & -17 \\
\hline It is difficult to answer & 24.4 & 27.3 & 26.6 & -1 & +2 \\
\hline \multicolumn{6}{|c|}{ In your immediate circle } \\
\hline More harmony and cohesion & 46.9 & 52.1 & 61.4 & +9 & +15 \\
\hline More disagreement and disunity & 29.3 & 23.2 & 18.3 & -5 & -11 \\
\hline It is difficult to answer & 23.9 & 24.7 & 20.3 & -4 & -4 \\
\hline \multicolumn{6}{|c|}{$\begin{array}{l}\text { The proportion of people who are willing or not willing to unite with others if their ideas and interests coincide } \\
\qquad \text { (in } \% \text { of the number of respondents) }{ }^{*}\end{array}$} \\
\hline Are willing to unite & 47.1 & 43.0 & 54.6 & +12 & +8 \\
\hline Are not willing to unite & 25.2 & 19.9 & 15.1 & -5 & -10 \\
\hline
\end{tabular}

Thus, a strong state power that is guided not only by its own interests, but also by public opinion; the importance of factors associated with social consciousness and behavior, rather than material factors; overcoming key challenges of the 1990s and 2000 s, not only in the material (improvement of the standard of living), but in the intangible (bridging social atomism, the growth of civil activity) perspective - these, in our view, are the key attributes of modern Russia. These are the signs that allow us to speak about the period of the 2010s as a new stage in Russia's development.

They do not arise only out of the rise of patriotic sentiment on the background of the "Ukrainian events". They are not even explained by the fact that during the last 20 years they were taking shape in the Russian society under the yoke of entirely different problems connected with the 
satisfaction of the basic need for national (and personal) security, and economic (and financial) stability. The modern period is deeply rooted in the mental specifics of the Russian people; as for all the other factors, they act only as a catalyst, turning out in the same place at the same time, largely because of a simple coincidence.

What can this new phase lead to? The consequences of the events of 2014 (in the first place - the accession of Crimea to the Russian Federation), according to G.V. Osipov, "can be crucial for our country, and they can be marked either by a new moral and economic recovery, or by the depression of disappointment and the deepest decline of everything" ${ }^{40}$. We share this opinion. There arises another question: what will be the determining factor in the country's progress toward prosperity?

Given the above mentioned characteristics of the new stage and their deep roots, we presume the key factors are the following:

\section{Shifting priorities from foreign policy} to domestic issues.

According to the results of the sociological surveys, the foundation of a new stage, which is the merger of the state and the society on the basis of a common "ideological" vector, is not solid. The Russian society was long enough preparing to changes, it was an evolutionary process. Therefore, in general, the Russian society has the very willingness to shift to a new stage in its development, and this willingness is quite strong.

\footnotetext{
${ }^{40}$ Ibidem. P. 12
}

However, we believe that the events of 2014 (Ukrainian conflict, accession of Crimea to Russia, etc.) have made this process revolutionary, rather than evolutionary. Over the last 15 years, the society seems to have been "longing" to feel a sense of pride for their country, especially in the international arena, and when such success has appeared, there came a certain state of "euphoria".

The problem is that all these successes are not managed exclusively within the country. They are all based on things that do not depend on Russia alone; that is, they make the Russian society dependent on external factors. In reality, all the current talk of a "new phase" are associated with the feeling of patriotism, national identity, ideological confrontation between Russian values and the values of Western civilization.

However, the main issues that worry the Russian society are internal. They were and are as follows: the standard of living and quality of life, elimination of social inequality, achievement of social justice, fight against corruption, improvement of the efficiency of social institutions, accessibility of "ordinary" citizens to their services, solution of the most pressing domestic problems.

These lingering issues have been unresolved already for many years; this fact was largely the cause of the "euphoria" after the events of 2013-2014, However, without addressing internal problems the positive trends in public opinion are "unstable", to put it mildly. 
As the people really felt the effects of the deteriorating economic situation in the second half of 2014 - early 2015 (which was caused partly by economic sanctions, partly by the consequences of a prolonged budget crisis in the regions), the agenda in the public opinion has changed immediately. The Russian mass media started talking about an increased level of anxiety among the people ${ }^{41}$, and also about the fact that the Ukrainian conflict, which still evokes the feeling of patriotism in the Russian people, in the public opinion gives way to economic problems and to the behavior of the Russians in the crisis conditions ${ }^{42}$.

By the end of 2014 there has been a notable increase (from 43 to $53 \%$ ) in the proportion of the people who consider the situation in the country to be tense and critical. When estimating the directions of social changes in the country over the past year, the Russians formed two groups comparable in quantity and pointing out changes for the better ( $45 \%$ ) or for the worse (43\%). At the same time, when we compare the results of surveys in different years, we note an increasing polarization of opinions on this issue among the population, which

${ }^{41}$ Bol'shinstvo rossiyan gotovo ne est' zapadnye produkty radi velichiya Rossii [The Majority of Russians are Ready to Give Up Western Food for the Greatness of Russia]. Moskovskii komsomolets [The Moscow Komsomol Member], January 28, 2015. Available at: http://www. mk.ru/politics/2015/01/28/bolshinstvo-rossiyan-gotovone-est-zapadnye-produkty-radi-velichiya-rossii.html

${ }^{42}$ Ot redaktsii: V soznanii rossiyan Krym otstupaet pod natiskom krizisa [Editorial: Crimea in the Minds of Russians is Retreating under the Onslaught of the Crisis]. Vedomosti [News], January 30, 2015. Available at: http://www.vedomosti.ru/opinion/news/38844121/ krizis-protiv-kryma indicates a growing differentiation of the actual situation among the representatives of different social groups ${ }^{43}$.

As for the people's expectations concerning the future of the country, they can be characterized as reservedly alarming: nearly half of the respondents agree that the country will experience difficult times; a quarter of the Russians believe that the country will be developing successful, and a similar proportion does not expect any fundamental changes in the country's development. Moreover, the Russians feel such anxiety with regard to the situation not only in Russia but also in the world. The social context of transformations going on in the country is reflected in the contradictory socio-psychological condition of the population. A little more than half of our fellow citizens assess their emotional condition as positive, and almost half of the Russians by the end of 2014 had negative socio-psychological feeling (a quarter felt anxiety, every one in five persons experienced apathy, annoyance, and more seldom - exacerbation) ${ }^{44}$.

According to ISEDT RAS, in the second half of 2014 there was a break off in the positive trend of public opinion concerning important indicators such as social mood and approval of the performance of the President of the Russian Federation; and in early 2015 there was a significant

\footnotetext{
${ }^{43}$ Rossiiskoe obshchestvo v kontekste novykh realii (tezisy o glavnom): informatsionno-analiticheskoe rezyume po itogam obshchenatsional'nogo issledovaniya [Russian Society in the Context of New Realities (Theses about the Most Important Things): the InformationAnalytical Summary of the Findings of a National Survey]. IS RAN [IS RAS]. Moscow, 2015. P. 3.

${ }^{44}$ Ibidem. P. 4.
} 
deterioration in self-evaluations of financial position (increase in the share of people who consider themselves to be "poor and extremely poor"), social mood, stock of patience. The situation improved in April 2015, but it is still unknown how sustainable these changes will be (tab. 5).

In the modern age of high technology and virtual networks people have the opportunity to compare the level and quality of life in different countries. Some people (and their number will only increase) do it on their own, without relying on the mass media that sometimes act as a kind of filter. Others come to the same conclusion, but a bit later, when the lack of proper management decisions in the right direction causes an actual decline in the standard of living and the inability to meet the basic social needs.

Table 5. Dynamics of key indicators of public opinion from February 2014 to April 2015 (\% of the number of respondents)*

\begin{tabular}{|c|c|c|c|c|c|c|c|c|c|c|c|}
\hline \multirow{2}{*}{ Answer option } & \multirow{2}{*}{$\begin{array}{l}\text { Feb. } \\
2014\end{array}$} & \multirow{2}{*}{$\begin{array}{l}\text { Apr. } \\
2014\end{array}$} & \multirow{2}{*}{$\begin{array}{l}\text { June } \\
2014\end{array}$} & \multirow{2}{*}{$\begin{array}{l}\text { Aug. } \\
2014\end{array}$} & \multirow{2}{*}{$\begin{array}{c}\text { Oct. } \\
2014\end{array}$} & \multirow{2}{*}{$\begin{array}{l}\text { Dec. } \\
2014\end{array}$} & \multirow{2}{*}{$\begin{array}{l}\text { Feb. } \\
2015\end{array}$} & \multirow{2}{*}{$\begin{array}{c}\text { Apr. } \\
2015\end{array}$} & \multicolumn{3}{|c|}{$\begin{array}{l}\text { Dynamics (+/-), } \\
\text { Apr. } 2015 \text { to... }\end{array}$} \\
\hline & & & & & & & & & $\begin{array}{l}\text { Feb. } \\
2014\end{array}$ & $\begin{array}{l}\text { June } \\
2014\end{array}$ & $\begin{array}{l}\text { Feb. } \\
2015\end{array}$ \\
\hline \multicolumn{12}{|c|}{ Level of approval of the RF President's performance } \\
\hline I approve & 56.1 & 62.8 & 66.6 & 66.4 & 66.8 & 66.0 & 66.3 & 67.5 & +11 & +1 & +1 \\
\hline I do not approve & 29.3 & 25.4 & 21.8 & 19.3 & 18.5 & 19.7 & 20.5 & 16.2 & -13 & -6 & -4 \\
\hline \multicolumn{12}{|c|}{ Social mood } \\
\hline Usual condition, good mood & 65.1 & 69.3 & 71.1 & 70.5 & 69.3 & 70.9 & 61.8 & 67.6 & +3 & -4 & +6 \\
\hline $\begin{array}{l}\text { I feel stress, anger, fear, } \\
\text { depression }\end{array}$ & 27.1 & 24.9 & 23.7 & 25.1 & 24.6 & 24.1 & 31.3 & 26.6 & -1 & +3 & -5 \\
\hline \multicolumn{12}{|c|}{ Stock of patience } \\
\hline $\begin{array}{l}\text { Everything is not so bad; it's } \\
\text { difficult to live, but it's possible } \\
\text { to stand it }\end{array}$ & 79.8 & 81.3 & 81.0 & 82.5 & 80.3 & 80.0 & 74.3 & 78.9 & -1 & -2 & +5 \\
\hline $\begin{array}{l}\text { It's impossible to bear such } \\
\text { plight }\end{array}$ & 12.3 & 11.1 & 13.4 & 12.8 & 12.1 & 13.6 & 17.3 & 14.9 & +3 & +2 & -2 \\
\hline \multicolumn{12}{|c|}{ Social self-identification } \\
\hline $\begin{array}{l}\text { The share of people who } \\
\text { consider themselves to have } \\
\text { average income }\end{array}$ & 44.2 & 43.1 & 42.0 & 44.1 & 43.5 & 42.3 & 38.3 & 36.7 & -8 & -5 & -2 \\
\hline $\begin{array}{l}\text { The share of people who } \\
\text { consider themselves to be poor } \\
\text { and extremely poor }\end{array}$ & 46.9 & 49.1 & 48.4 & 49.6 & 49.3 & 51.0 & 53.3 & 51.6 & +5 & +3 & -2 \\
\hline \multicolumn{12}{|c|}{ Consumer sentiment index } \\
\hline Index value, points & 91.5 & 90.3 & 90.5 & 87.1 & 84.0 & 82.3 & 75.7 & 73.4 & -18 & -17 & -2 \\
\hline \multicolumn{12}{|c|}{ Protest potential } \\
\hline Index value, points & 15.9 & 17.7 & 18.4 & 22.4 & 19.7 & 18.9 & 20.7 & 20.0 & +4 & +2 & -1 \\
\hline
\end{tabular}


The results of recent surveys (from June 2014) show that public opinion on all the key aspects will not and should not be based solely on ideology, victories in the information war with the U.S. and on optimistic views of the future of Russia as the center of a multipolar world. Figuratively speaking, we can use it to win the war, but we cannot use it as a foundation of peace.

The presence of lingering unsettled problems brought to nothing the consolidation of Russian society after the speech of the President of the Russian Federation in Munich in 2007. For the same reason, the beginning of Vladimir Putin's third presidential term has not become the starting point of a new phase in the life of the country. Today Russia may fall into a similar "trap", if the authorities do not focus their attention on the main social issues that comprise internal, first of all, socio-economic, problems of the country.

2. Improving the effectiveness of management decisions by taking into consideration the opinions of leading Russian scientists, as well as the opinions of managers of a lower "link" in the structure of public administration.

The second factor that affects the sustainability of positive trends in social development is closely linked to the first one. What is necessary for effective solution of the most pressing internal problems in the country? Today, the best representatives of domestic economic and social sciences (R.S. Grinberg, V.V. Ivanter,
A.D. Nekipelov, S.Yu. Glazyev, S.S. Gubanov, G.V. Osipov, M.K. Gorshkov, etc.) propose the answer to this question in the form of very specific and clear measures, and the algorithm of actions; but their recommendations are not always used as the basis for management decisions. The policy of extreme liberalism pursued by the government, and the withdrawal of the state from the spheres of economic and social policy do not generate the necessary request from the state, first of all, to the Russian Academy of Sciences, to carry out research into the social environment and objective analysis of changes in the society at the national and regional levels ${ }^{45}$.

G.V. Osipov points out that "the new century, according to the forecasts and conclusions of futurology, should be the century of the triumph of scientific worldview and show the world the qualitatively new principles and approaches to the organization of a society striving toward the unification of the global community, to the management of each individual state and society. It is known that the global scientific community names the twenty-first century "the century of social sciences". Yet, to be honest, it is not represented sufficiently in global information networks; and, most importantly, public, corporate and private investors do not show enough willingness

${ }^{45}$ Ilyin V.A., Shabunova A.A. Sotsiologicheskoe izmerenie effektivnosti gosudarstvennogo upravleniya [Sociological Assessment of Public Administration Efficiency]. Ekonomicheskie i sotsial'nye peremeny: fakty, tendentsii, prognoz [Economic and Social Changes: Facts, Trends, Forecast], 2014, no. 2 (32), p. 20. 
to finance social and humanitarian research and promote their findings in everyday top management practices" ${ }^{46}$. Thus, raising the status of scientific knowledge in the process of managerial decision-making is not just a necessity for Russia; it is the spirit of the times in the entire global community; therefore, the one who is the first to understand, accept and implement this, will be the winner.

Furthermore, only scientific knowledge, as a foundation of lawmaking, is able to prevent getting into a "trap" of imitation, which J. T. Toshchenko calls one of the main causes of social apathy, distrust in the authority, low electoral turnout and the general anomie of the society ${ }^{47}$. In modern conditions, when much in life depends on ideology, national identity and patriotism, it is very important to avoid "substitution of activity for imitation at all the levels of social organization - federal, regional and local, in many organizations and even with regard to individuals" 48 .

The same can be said about the fact that federal authorities do not always listen to the opinions of heads of the RF subjects, and regional authorities do not always take into consideration the problems that

${ }^{46}$ Osipov G.V. Ne upustit' predostavivshiisya shans! [Do not Miss This Chance!]. Sotsiologiya i ekonomika sovremennoi sotsial'noi real'nosti. Sotsial'naya i sotsial'nopoliticheskaya situatsiya v Rossii v 2013 godu [Sociology and Economics of the Current Social Reality. Social and Socio-Political Situation in Russia in 2013]. Moscow: ISPI RAN. P. 9.

${ }^{47}$ Toshchenko Zh.T. Novye liki deyatel'nosti: imitatsiya [New Images of Activity: Imitation]. Sotsiologicheskie issledovaniya [Sociological Studies], 2012, no. 12, p. 35.

${ }^{48}$ Ibidem. P.23. the heads of municipalities speak about ${ }^{49}$. Significant differentiation of the subjects of the Russian Federation in the socioeconomic, territorial, historical, cultural, moral, demographic, and other aspects has long been one of the key issues that hinder the effectiveness of management decisions made at the federal level.

More than once has the President of the Russian Federation stressed the importance of the regional and municipal levels of government ("I think the most important task is to clarify the general principles of local self-government organization, develop strong, independent, financially sustainable local authorities" ${ }^{50}$ ).

The lower the level of public administration in the overall structure of the power vertical is, the closer its representatives are to the real concerns of the population. And, most importantly, it is the lower levels of power that have greater opportunities for the development of various forms of

${ }^{49}$ The report of E.S. Savchenko at the meeting of the State Council on September 18,2014 can be an example of such a situation. In his report the Belgorod Oblast Governor set out a clear mechanism of the new model of economic growth, asked the Government to renounce some of the myths that have been ingrained in the consciousness since the 1990s, and also to make a list of projects focused on import substitution, and more importantly, to provide them with a new mechanism of support (source: Savchenko E.S. Doklad na zasedanii gossoveta [Report on the Session of the State Council]. Ofitsial'nyi sait gubernatora Belgorodskoi oblasti [Official Website of the Belgorod Oblast Governor]. Available at: http://www.savchenko.ru/events/2821.html).

${ }^{50}$ Poslanie Prezidenta RF V.V. Putina Federal'nomu Sobraniyu RF ot 12 dekabrya 2013 g. Stenogramma [The Address of the President of the Russian Federation V.V. Putin to the Federal Assembly of the Russian Federation of December 12, 2013: Transcript]. Informatsionnopravovoi portal "Garant" [Information and Legal Portal "Garant”]. Available at: http://base.garant.ru/70534308/ 
interaction between the society and public administration bodies, which is especially important taking into consideration the specifics of the present stage, which we have mentioned above.

For the President of the Russian Federation the annual "direct line" (a live television phone-in) is one of the main forms of direct interaction with the public; as for the governors and heads of municipalities, they can use such forms of communication with people much more often; and they can focus their attention on the residents of more remote and economically weak areas; and the subject of discussions can include the most common issues, the resolution of which is important for social perception and social well-being.

Thus, the scientific community has direct answers to the most important questions that affect the standard of living and quality of life of the population, address the most pressing issues that define the "agenda" of public opinion. These responses should be heard and taken into account in development management decisions. Then they will become a contributing factor to the further progressive development of the country.

3. The quality of sociological knowledge.

If the work of government should be focused on the satisfaction of social demands $^{51}$ (as reflected in the May 2012

${ }^{51}$ Bartsits I.N. Konstitutsionnaya demokratiya eto svobodnye vybory plyus internetizatsiya vsei strany [Constitutional Democracy Means Free Elections Plus Internetization of the Whole Country]. Sotsis [Sociological Studies], 2013, no. 9, p. 116. decrees of the President ${ }^{52}$ ); if public opinion becomes one of the main criteria of public administration efficiency and, finally, if national security primarily depends on the level of social tension within the country, then sociological science, which accumulates knowledge about society, its mental characteristics and current trends of social consciousness, perception and behavior, becomes the main tool providing the link between the population and authorities.

"The scientific understanding of individual and collective social behavior, which leads to their control, is most likely, the most pressing challenge that humanity is facing today", writes G.V. Osipov, citing the opinion of Nobel laureate Dutch economist J. Tinbergen. "Hence, it follows that in this situation only the social sciences and humanities, whose object of research is people, their social actions and social reality created by them, can introduce scientific rationality in multi-directional, spontaneous and irresponsible actions of an individual, to bring them to a common denominator, eliminating and neutralizing global threats, which hang over mankind like the sword of Damocles" 53 .

\footnotetext{
${ }^{52} \mathrm{Ob}$ osnovnykh napravleniyakh sovershenstvovaniya sistemy gosudarstvennogo upravleniya: ukaz Prezidenta RF ot 7 maya $2012 \mathrm{~g}$. № 601 [About the Main Directions of Improving the System of Public Administration: the Decree of the President of the Russian Federation of May 7, 2012]. Informatsionno-pravovoi portal "Garant" [Information-Legal Portal "Garant"]. Available at: http:// base.garant.ru/70170942/\#ixzz3YDD9ERG3

${ }^{53}$ Osipov G.V. Ne upustit' predostavivshiisya shans! [Do not Miss This Chance!]. Sotsiologiya i ekonomika sovremennoi sotsial'noi real'nosti. Sotsial'naya i sotsial'nopoliticheskaya situatsiya $v$ Rossii v 2013 godu [Sociology and Economics of the Current Social Reality. Social and Socio-Political Situation in Russia in 2013]. Moscow: ISPI RAN. P. 11.
} 
Accordingly, the situation in the country largely depends on the quality of sociological knowledge - its reliability, depth, and timeliness. And the quality of sociological knowledge depends upon the solution of fundamental problems that currently exist in domestic sociology and are highlighted at the all-Russian sociological forums ${ }^{54}$ and in scientific articles ${ }^{55}$.

${ }^{54}$ For example: Rezolyutsii I IV Vserossiiskogo sotsiologicheskogo kongressa [Resolutions I of the 4th All-Russian Sociological Congress]. Ofitsial'nyi sait Rossiiskogo obshchestva sotsiologov [Official Website of the Russian Society of Sociologists]. Available at: http:// www.ssa-rss.ru/; Zhukov V.I. Sotsiologiya v sovremennoi Rossii: doklad na Uchreditel'nom s"ezde Soyuza sotsiologov Rossii [Sociology in Modern Russia: the Report at the Constituent Congress of the Union of Sociologists of Russia]. Sotsis [Sociological Studies], 2007, no. 12, pp. 8-13); Osipov G.V. Vozrozhdenie sotsiologii v Rossii: doklad na Yubileinoi nauchnoi sessii RAN 26 marta 2008 g. [The Revival of Sociology in Russia: the Report at the Anniversary Scientific Session of the Russian Academy of Sciences, March 26, 2008]. Ofitsial'nyi sait Instituta sotsiologii Rossiiskoi akademii nauk [Official Website of the Institute of Sociology of the Russian Academy of Sciences]. Available at: http://www.isras.ru/?page_id=699); Gorshkov M.K. Rossiiskaya sotsiologiya v postsovetskoi Rossii: sostoyanie i problemy razvitiya: doklad na Vserossiiskoi nauchno-prakticheskoi konferentsii "Obshchestvo i sotsiologiya v sovremennoi Rossii” (13-15 noyabrya 2014 g., g. Vologda) [Russian Sociology in Post-Soviet Russia: State and Problems of Development: the Report at the All-Russian Research-to-Practice Conference "Society and Sociology in Modern Russia" (November 13-15, 2014, Vologda)]. Materialy Vserossiiskoi nauchnoprakticheskoi konferentsii "Obshchestvo i sotsiologiya $v$ sovremennoi Rossii”, posvyashchennoi XX godovshchine prazdnovaniya Dnya sotsiologa $v$ Rossiiskoi Federatsii [Proceedings of the All-Russian Research-to-Practice Conference "Society and Sociology in Modern Russia", Devoted to the 20th Anniversary of the Sociologist's Day in the Russian Federation]. Vol. 1. Vologda: ISERT RAN, 2015. Pp. 10-17.

${ }^{55}$ For example: Osipov G.V. O roli nauchnogo znaniya v upravlenii sovremennoi sotsial'noi real'nost'yu [On the Role of Scientific Knowledge in the Management of Modern Social Reality]. Ezhegodnyi doklad ISPI RAN "Sotsial'naya i sotsial'no-politicheskaya situatsiya v Rossii: analiz i prognoz" [Annual Report of ISPR RAS "Social and Socio-Political Situation in Russia: Analysis and Forecast]. Doklad "Sovremennaya sotsial'naya real'nost' Rossii i gosudarstvennoe upravlenie. Sotsial'naya i sotsial'no-politicheskaya situatsiya v Rossii v 2012
These problems include:

- insufficient authority of the sociologist;

- the need for greater involvement of social scientists in addressing the most acute problems of society through the creation of new communication channels and platforms of interaction with government officials, public entities, and civil society;

- significant gap between fundamental theoretical knowledge and its practical application;

- underdeveloped mechanism of social expert assessment of the laws adopted;

- lack of a unified system approach in the development of sociological research at the regional level; coordination of sociological research on the federal and regional levels;

- improvement of the quality of sociological education, etc.

Today the solution of these and many other problems of domestic sociology largely determines the quality of the relationship between the state and society at all the levels of government; it also determines how well the authorities understand actual problems that the population faces. Therefore, if we do not

godu" [Report "Contemporary Social Reality of Russia and Public Administration. Social and Socio-Political Situation in Russia in 2012]. Vol. 1. Moscow: ISPI RAN, 2014. Pp. 6-11; Toshchenko Zh.T. Vremya Akme sotsiologicheskim issledovaniyam 40 let [Time of Acme Sociological Research Celebrates Its 40th Anniversary]. Sotsis [Sociological Studies], 2014, no. 7 (363), pp. 3-7; Ilyin V.A., Shabunova A.A. Sotsiologicheskoe izmerenie effektivnosti gosudarstvennogo upravleniya [Sociological Assessment of Public Administration Efficiency]. Ekonomicheskie $i$ sotsial'nye peremeny: fakty, tendentsii, prognoz [Economic and Social Changes: Facts, Trends, Forecast], 2014, no. 2 (32), pp. 18-35. 
want "to miss this opportunity", today it is very important to use the mechanisms that actually exist and can be used to systematize social research.

For example, much depends on the status of the Russian Academy of Sciences, which can play the role of an "independent institute, which coordinates sociological research, enhances support to promising regional scientific schools and young scientists, and the search for new ways to include the results of Russian sociology in the global science" 56 . The Federal Law "On strategic planning in the Russian Federation", which was welcomed by many scholars (E.V.Zhirnel', O.S. Sukharev, A. Vasserman, M. Delyagin, etc.), can become an important tool that can help "embed" sociological knowledge in the system of public administration; in fact, it is "a necessary step for the formation of a unified system of strategic planning that covers the federal, regional and municipal levels" ${ }^{57}$.

Modern sociological science does not claim to become a support to the management system. Ware talking about the integration of sociological knowledge in the structure of the legislative process. The integration of sociology and social sciences

${ }^{56}$ Ilyin V.A., Shabunova A.A. Sotsiologicheskoe izmerenie effektivnosti gosudarstvennogo upravleniya [Sociological Assessment of Public Administration Efficiency]. Ekonomicheskie i sotsial'nye peremeny: fakty, tendentsii, prognoz [Economic and Social Changes: Facts, Trends, Forecast], 2014, no. 2 (32), p. 30.

${ }^{57}$ Uskova T.V., Chekavinskii A.N. Zakon o strategicheskom planirovanii v Rossiiskoi Federatsii: dostoinstva i nereshennye voprosy (ekspertnaya otsenka) [Law on Strategic Planning in the Russian Federation: Advantages and Unresolved Issues (Expert Evaluation)]. Ekonomicheskie i sotsial'nye peremeny: fakty, tendentsii, prognoz [Economic and Social Changes: Facts, Trends, Forecast], 2014, no. 4 (34), p. 64. in the "culture of power" will make it possible on the basis of specific studies to identify key areas and means of implementation of socially significant goals, to provide a scientific justification, to forecast the consequences of decisions, to assess the implemented measures in accordance with clear criteria of effectiveness ${ }^{58}$. Through the generalization of international and domestic practice sociology offers the clear regulation of legislative activity, the consolidation of which at the legislative level "will make it possible not only to improve the system of legislation, but also to create a new type of state governance on the basis of scientific knowledge. This will make it possible to move from a "method of patching holes" to preventive management based on a system legislative level" ${ }^{59}$.

Thus, the above-mentioned features of modern Russia allow us to speak about the period of 2013-2014 as the beginning of a new phase in the life of the Russian society.

The theory on creative destruction developed by economist Joseph Schumpeter can be applied to the modern understanding of state management in Russia. The essence of the theory is as follows: something new appears very rarely, usually there is some rearrangement, recombination of

${ }^{58}$ Osipov G.V. Istoricheskaya missiya rossiiskoi sotsiologii: problemy i perspektivy [Historical Mission of Russian Sociology: Problems and Prospects]. Materialy Vserossiiskoi nauchno-prakticheskoi konferentsii "Obshchestvo i sotsiologiya v sovremennoi Rossii", posvyashchennoi XX godovshchine prazdnovaniya Dnya sotsiologa $v$ Rossiiskoi Federatsii. [Proceedings of the All-Russian Research-to-Practice Conference "Society and Sociology in Modern Russia", Devoted to the 20th Anniversary of the Sociologist's Day in the Russian Federation]. Vol. 1. Vologda: ISERT RAN, 2015. P. 19.

59 Ibidem. P. 24. 
factors within the existing paradigm in the development ${ }^{60}$. Historically developed mental characteristics, the legacy of the Soviet era, transformation processes in the post-Soviet period, and the events of 2013-2014 became recombined factors in the new stage of the Russian history.

The inevitable future changes of social reality necessitate the transition to the new system of society management, which implies the rejection of the traditional method of trial and error and the adoption of socially important government decisions on the basis of a comprehensive scientific analysis and mathematically precise and accurate calculations ${ }^{61}$.

The Ukrainian crisis has not yet become the thing of the past, but public consciousness is moving on. Today, in early 2015, the society and the state are focused on solving domestic economic problems, on the improvement of the quality of life regardless of the situation on the international arena. This is clearly evidenced by the issues raised during the "direct lines" with Russian President Vladimir Putin in 2013-2015: after discussing the issues related to international politics and national selfdetermination (which were the main topics of the "direct line" in 2014), the 2015 "agenda" again focuses on the internal socio-economic problems, only now they are considered not in the context of the "May decrees" (as it was in 2013), but in the context of the functioning of the Russian economy under the sanctions.

The society shares the view of the head of state about the necessity to "find better ways to manage these (socio-economic. Author's note) processes by ourselves, in our own country" 62 , and it allows us to look into the future with confidence and optimism.

\section{References}

1. Avtory “Pereloma” kommentiruyut valdaiskuyu rech' Putina [The Authors of The Breaking Point Comment on Vladimir Putin's Valdai Speech]. Available at: http://www.rodon.org/society-131007122213

2. Akopov P.E. Valdai posle Myunkhena [Valdai after Munich]. Gazeta "Vzglyad” [Newspaper “Outlook”], September 20, 2013. Available at: http://vz.ru/politics/2013/9/20/651345.html

3. Auzan A.A. Obshchestvennyi dogovor i grazhdanskoe obshchestvo [Social Contract and Civil Society]. Available at: http:// polit.ru/article/2005/01/11/auzan/

4. Bartsits I.N. Konstitutsionnaya demokratiya - eto svobodnye vybory plyus internetizatsiya vsei strany [Constitutional Democracy Means Free Elections Plus Internetization of the Whole Country]. Sotsis [Sociological Studies], 2013, no. 9, pp. 119-120.

5. Bol'shinstvo rossiyan gotovo ne est' zapadnye produkty radi velichiya Rossii [The Majority of Russians are Ready to Give Up Western Food for the Greatness of Russia]. Moskovskii komsomolets [The Moscow Komsomol Member], January 28, 2015. Available at: http://www.mk.ru/politics/2015/01/28/bolshinstvo-rossiyan-gotovo-ne-est-zapadnye-produkty-radivelichiya-rossii.html

${ }^{60}$ Shumpeter J.A. Teoriya ekonomicheskogo razvitiya [The Theory of Economic Development]. Moscow: Progress, 1982.

${ }^{61}$ Osipov G.V. Ne upustit' predostavivshiisya shans! [Do not Miss This Chance!]. Sotsiologiya i ekonomika sovremennoi sotsial'noi real'nosti. Sotsial'naya i sotsial'no-politicheskaya situatsiya v Rossii v 2013 godu [Sociology and Economics of the Current Social Reality. Social and Socio-Political Situation in Russia in 2013]. Moscow: ISPI RAN. P. 18.

${ }^{62}$ During the "direct line" in April 2015, the RF President also pointed out: "As for the sanctions, they certainly contribute to our difficulties, but still it is not the main thing" (source: Stenogramma "Pryamoi linii" s Prezidentom RF V.V. Putinym ot 16 aprelya 2015 [Transcript of "Direct Line" with Russian President Vladimir Putin, April 16, 2015]. Ofitsial'nyi sait Prezidenta RF [Official Website of the RF President]. Available at: http://kremlin.ru/events/president/ news/49261). 
6. Vse bol'she rossiyan polozhitel'no otnosyatsya k Stalinu [More and More Russians Have a Positive Attitude towards Stalin]. Vedomosti [The News], March 30, 2015. Available at: http://www.vedomosti.ru/politics/articles/2015/03/31/vse-bolsherossiyan-polozhitelno-otnosyatsya-k-stalinu-levada-tsentr

7. Gorshkov M.K. Rossiiskaya sotsiologiya v postsovetskoi Rossii: sostoyanie i problemy razvitiya: doklad na Vserossiiskoi nauchno-prakticheskoi konferentsii "Obshchestvo i sotsiologiya v sovremennoi Rossii” (13-15 noyabrya 2014 g., g. Vologda) [Russian Sociology in Post-Soviet Russia: State and Problems of Development: the Report at the All-Russian Research-toPractice Conference "Society and Sociology in Modern Russia" (November 13-15, 2014, Vologda)]. Materialy Vserossiiskoi nauchno-prakticheskoi konferentsii "Obshchestvo i sotsiologiva v sovremennoi Rossii", posvyashchennoi XX godovshchine prazdnovaniya Dnya sotsiologa v Rossiiskoi Federatsii [Proceedings of the All-Russian Research-to-Practice Conference "Society and Sociology in Modern Russia", Devoted to the 20th Anniversary of the Sociologist's Day in the Russian Federation]. Vol. 1. Vologda: ISERT RAN, 2015. Pp. 10-17.

8. Gorshkov M.K. "Russkaya mechta": opyt sotsiologicheskogo izmereniya [A "Russian Dream": the Experience of Sociological Assessment]. Sotsiologicheskie issledovaniya [Sociological Studies], 2012, no. 12, pp. 3-11.

9. Doklad o sostoyanii grazhdanskogo obshchestva v Rossiiskoi Federatsii za 2014 god [Report on the State of Civil Society in the Russian Federation for 2014]. Available at: http://www.oprf.ru/documents/1151/

10. Dugin A.G. Ekho "myunkhenskoi rechi". Prezident Putin vstupil na put' geopoliticheskoi revolyutsii [Echo of the Munich Speech. President Putin has Embarked on the Path of Geopolitical Revolution]. Available at: http://oko-planet.su/politik/ politikrus/230532-aleksandr-dugin-eho-myunhenskoy-rechi-prezident-putin-vstupil-na-put-geopoliticheskoy-revolyucii. html

11. Zhukov V.I. Sotsiologiya v sovremennoi Rossii: doklad na Uchreditel'nom s"ezde Soyuza sotsiologov Rossii [Sociology in Modern Russia: the Report at the Constituent Congress of the Union of Sociologists of Russia]. Sotsis [Sociological Studies], 2007, no. 12, pp. 4-12.

12. Zuikov A.V. Institut prezidentstva v Rossii: konstitutsionnaya model', sovremennye realii i perspektivy razvitiya [The Institution of the Presidency in Russia: the Constitutional Model, Current Realities and Prospects]. Konstitutsionnyi vestnik [Constitutional Herald], 2008, no. 1(19), pp. 171-179.

13. Ilyin V.A., Shabunova A.A. Sotsiologicheskoe izmerenie effektivnosti gosudarstvennogo upravleniya [Sociological Assessment of Public Administration Efficiency]. Ekonomicheskie i sotsial'nye peremeny: fakty, tendentsii, prognoz [Economic and Social Changes: Facts, Trends, Forecast], 2014, no. 2 (32), pp. 18-35. - DOI: 10.15838/esc/2014.2.32.3

14. Kalina F.V., Kurskova G.Yu. Sotsiologiya zakonodatel'stva i pravotvorcheskii protsess [Sociology of Law and the Law-Making Process]. Yurisprudentsiya [Jurisprudence], 2003, no. 1. Available at: http://pravorggu.ru/2004_2/15kalina-kurskovasotsiologiya_zakonodatelstva_13.shtml

15. Materialy IV Vserossiiskogo sotsiologicheskogo kongressa “Sotsiologiya i obshchestvo: global'nye vyzovy i regional'noe razvitie" [Proceedings of the 4th All-Russian Sociological Congress "Sociology and Society: Global Challenges and Regional Development]. Ofitsial'nyi sait Rossiiskogo obshchestva sotsiologov [Official Website of the Russian Society of Sociologists]. Available at: http://www.ssa-rss.ru/files/File/congress2012/part3.pdf

16. Makhmudov R. Valdaiskaya rech' Vladimira Putina: kriticheskii analiz [Vladimir Putin's Valdai Speech: a Critical Analysis]. Informatsionnyi portal http://www. 12news.uz/[Information Portal http://www.12news.uz/]. Available at: http://www.12news. uz/news/2013/09/30/valdaiskaya-rech'-vladimira-putina-kri/

17. Migranyan A.M. Narod i lider nashli drug druga [The People and the Leader have Found Each Other]. Gazeta "Izvestiya" [The News], June 12, 2013. Available at: http://izvestia.ru/news/551898

18. Osipov G.V. Vozrozhdenie sotsiologii v Rossii: doklad na Yubileinoi nauchnoi sessii RAN 26 marta 2008 g. [The Revival of Sociology in Russia: the Report at the Anniversary Scientific Session of the Russian Academy of Sciences, March 26, 2008]. Ofitsial'nyi sait Instituta sotsiologii Rossiiskoi akademii nauk [Official Website of the Institute of Sociology of the Russian Academy of Sciences]. Available at: http://www.isras.ru/?page_id=699)

19. Osipov G.V. Vystuplenie na IV Vserossiiskom sotsiologicheskom Kongresse "Sotsiologiya v sisteme nauchnogo upravleniya obshchestvom" 2 fevralya 2012 g. [Speech at the 4th All-Russian Sociological Congress "Sociology in the System of Scientific Management of Society", February 2, 2012]. Press-reliz IV Vserossiiskogo sotsiologicheskogo kongressa [Press Release of the 4th All-Russian Sociological Congress]. Available at: http://www.isras.ru/index.php?page_id=1665

20. Osipov G.V. Istoricheskaya missiya rossiiskoi sotsiologii: problemy i perspektivy [Historical Mission of Russian Sociology: Problems and Prospects]. Materialy Vserossiiskoi nauchno-prakticheskoi konferentsii "Obshchestvo i sotsiologiya v sovremennoi Rossii”, posvyashchennoi XX godovshchine prazdnovaniya Dnya sotsiologa v Rossiiskoi Federatsii. [Proceedings of the All-Russian Research-to-Practice Conference "Society and Sociology in Modern Russia", Devoted to the 20th Anniversary of the Sociologist's Day in the Russian Federation]. Vol. 1. Vologda: ISERT RAN, 2015. Pp. 18-26.

21. Osipov G.V. Ne upustit' predostavivshiisya shans! [Do not Miss This Chance!]. Sotsiologiya i ekonomika sovremennoi sotsial'noi real'nosti. Sotsial'naya i sotsial'no-politicheskaya situatsiya v Rossii v 2013 godu [Sociology and Economics of the Current Social Reality. Social and Socio-Political Situation in Russia in 2013]. Moscow: ISPI RAN. Pp. 6-18.

22. Osipov G.V. O roli nauchnogo znaniya v upravlenii sovremennoi sotsial'noi real'nost'yu [On the Role of Scientific Knowledge in the Management of Modern Social Reality]. Ezhegodnyi doklad ISPI RAN "Sotsial'naya i sotsial'no-politicheskaya situatsiya v Rossii: analiz i prognoz" [Annual Report of ISPR RAS "Social and Socio-Political Situation in Russia: Analysis and Forecast]. Doklad "Sovremennaya sotsial'naya real'nost' Rossii i gosudarstvennoe upravlenie. Sotsial'naya i sotsial'nopoliticheskaya situatsiya v Rossii v 2012 godu" [Report "Contemporary Social Reality of Russia and Public Administration. Social and Socio-Political Situation in Russia in 2012]. Vol. 1. Moscow: ISPI RAN, 2014. Pp. 6-11. 
23. Ot redaktsii: V soznanii rossiyan Krym otstupaet pod natiskom krizisa [Editorial: Crimea in the Minds of Russians is Retreating under the Onslaught of the Crisis]. Vedomosti [News], January 30, 2015. Available at: http://www.vedomosti.ru/opinion/ news/38844121/krizis-protiv-kryma

24. Poslanie Prezidenta RF V.V. Putina Federal'nomu Sobraniyu RF ot 12 dekabrya 2013 g. Stenogramma [The Address of the President of the Russian Federation V. V. Putin to the Federal Assembly of the Russian Federation of December 12, 2013: Transcript]. Informatsionno-pravovoi portal "Garant" [Information and Legal Portal "Garant"]. Available at: http://base. garant.ru/70534308/

25. Putin V.V. Rech' na zasedanii mezhdunarodnogo diskussionnogo kluba "Valdai" 19 sentyabrya 2013 g. [Vladimir Putin's Speech at the Session of the Valdai International Discussion Club, September 19, 2013]. Available at: http://www.kremlin.ru/events/ president/news/19243

26. Putin V.V. Rech' na soveshchanii o khode ispolneniya ukazov Prezidenta 7 maya 2012 goda [Speech at the Meeting on the Implementation of the Presidential Decrees of May 7, 2012]. Ofitsial'nyi sait Prezidenta RF [Official Website of the President of the Russian Federation]. Available at: http://www.kremlin.ru/news/18039

27. Putin V.V. Rossiya sosredotachivaetsya - vyzovy, na kotorye my dolzhny otvetit' [Russia Muscles Up - the Challenges We must Rise to Face] Izvestiya [News], January 16, 2012. Available at: http://izvestia.ru/news/511884

28. Rezolyutsii I IV Vserossiiskogo sotsiologicheskogo kongressa [Resolutions I of the 4th All-Russian Sociological Congress]. Ofitsial'nyi sait Rossiiskogo obshchestva sotsiologov [Official Website of the Russian Society of Sociologists]. Available at: http:// www.ssa-rss.ru/

29. Rossiiskoe obshchestvo $\mathrm{v}$ kontekste novykh realii (tezisy o glavnom): informatsionno-analiticheskoe rezyume po itogam obshchenatsional'nogo issledovaniya [Russian Society in the Context of New Realities (Theses about the Most Important Things): the Information-Analytical Summary of the Findings of a National Survey]. IS RAN [IS RAS]. Moscow, $2015.58 \mathrm{p}$.

30. Savchenko E.S. Doklad na zasedanii gossoveta [Report on the Session of the State Council]. Ofitsial'nyi sait gubernatora Belgorodskoi oblasti [Official Website of the Belgorod Oblast Governor]. Available at: http://www.savchenko.ru/events/2821. html

31. Sil'vestrov S.N. Doklad na kruglom stole "Institut prezidentstva v Rossii: pravovye osnovy i rol' v modernizatsii obshchestva" 8 iyunya 2011 g. [The Round Table Report "The Institution of the Presidency in Russia: Legal Basis and Role in the Modernization of Society", June 8, 2011]. Available at: http://education.law-books.ru/index.php?page=kruglyj-stol

32. Simonyan R.Kh. Est' li osobyi "russkii put"”? (polemicheskie zametki) [Is There a Special "Russian Way"? (Polemical Notes)]. Sotsis [Sociological Studies], 2013, no. 7, pp. 137-148.

33. Stenogramma "Pryamoi linii" s Prezidentom RF V.V. Putinym ot 25.04.2013 [Transcript of "Direct Line" with Russian President Vladimir Putin, April 25, 2013]. Rossiiskaya Gazeta [Russian Newspaper]. Available at: http://www.rg.ru/2013/04/25/ stenogramma-site.html

34. Stepanov A.D. Rossiya i mir vstupayut v novuyu epokhu, v kotoroi ot nashei strany budet zaviset' mnogoe [Russia and the World are Entering a New Era in Which a Lot will Depend on Our Country]. Informatsionno-analiticheskaya sluzhba "Russkaya narodnaya liniya" [Information-Analytical Service "Russian National Line"]. Available at: http://ruskline.ru/news rl/2013/09/20/valdajskaya_rech_putina

35. Toshchenko Zh.T. Vremya Akme - sotsiologicheskim issledovaniyam 40 let [Time of Acme - Sociological Research Celebrates Its 40th Anniversary]. Sotsis [Sociological Studies], 2014, no. 7 (363), pp. 3-7.

36. Toshchenko Zh.T. Novye liki deyatel'nosti: imitatsiya [New Images of Activity: Imitation]. Sotsiologicheskie issledovaniya [Sociological Studies], 2012, no. 12, pp. 23-36.

37. Toshchenko Zh.T. Sotsial'noe nastroenie - fenomen sotsiologicheskoi teorii i praktiki [Social Mood - a Phenomenon of Sociological Theory and Practice]. SOTSIS [Sociological Studies], 1998, no. 1, pp. 21-34.

38. Tret'yakov V.T. Doklad na kruglom stole "Institut prezidentstva v Rossii: pravovye osnovy i rol'v modernizatsii obshchestva" 8 iyunya $2011 \mathrm{~g}$. [The Round Table Report "The Institution of the Presidency in Russia: Legal Basis and Role in the Modernization of Society”, June 8, 2011]. Available at: http://education.law-books.ru/index.php?page=kruglyj-stol

39. Ukaz Prezidenta RF ot 7 maya 2012 g. № 601 "Ob osnovnykh napravleniyakh sovershenstvovaniya sistemy gosudarstvennogo upravleniya" [The Decree of the RF President of May 7, 2012 No. 601 "On the Main Directions of Improving the System of Public Administration]. Informatsionno-pravovoi portal "Garant" [Information and Legal Portal "Garant"]. Available at: http://base.garant.ru/70170942/\#ixzz3YDD9ERG3

40. Uskova T.V., Chekavinskii A.N. Zakon o strategicheskom planirovanii v Rossiiskoi Federatsii: dostoinstva i nereshen-nye voprosy (ekspertnaya otsenka) [Law on Strategic Planning in the Russian Federation: Advantages and Unresolved Issues (Expert Evaluation)]. Ekonomicheskie i sotsial'nye peremeny:fakty, tendentsii, prognoz [Economic and Social Changes: Facts, Trends, Forecast], 2014, no. 4 (34), pp. 63-67. - DOI: 10.15838/esc/2014.4.34.6

41. Chuguenko V.M., Bobkova E.M. Novye tendentsii v issledovanii sotsial'nogo samochuvstviya naseleniya [New Trends in Research on Social Well-Being of the Population]. Sotsiologicheskie issledovaniya [Sociological Studies], 2013, no. 1, pp. $15-23$.

42. Shumpeter J.A. Teoriya ekonomicheskogo razvitiya [The Theory of Economic Development]. Moscow: Progress, 1982.

43. Yadov V.A. Sovremennaya teoreticheskaya sotsiologiya kak kontseptual'naya baza issledovaniya rossiiskikh transformatsii: Kurs lektsii dlya studentov magistratury po sotsiologii. Izd. vtoroe, ispravl. i dopoln. [Modern Theoretical Sociology as a Conceptual Framework of the Research on Russian Transformations: a Course of Lectures for Master's Degree Students in Sociology]. Second edition, revised and supplemented. Saint Petersburg: Intersotsis, 2009. 138 p. Available at: http://www.isras.ru/index.php?page id=1330\&id=1393\&param=http://www.isras.ru/files/File/Publication/Sovremennaya_teoret_sociol_2009_Yadov.pdf 